\title{
Role of Nonsense, Frameshift, and Missense Suppressor tRNAs in Mammalian Cells
}

\author{
D. Hatfield ${ }^{1}$, B. J. LeE ${ }^{1}$, D. W. E. Smith ${ }^{2}$, and S. Oroszlan ${ }^{3}$
}

\section{A. Introduction}

Three classes of point mutations occur in nature: (1) missense; (2) nonsense; and (3) frameshift. Aminoacyl-tRNAs, which suppress mutations within each class, have been characterized in microorganisms; excellent reviews covering these studies have been published (Eggertsson and Söll 1988; Hill 1975; Körner et al. 1978; Murgola 1985, 1989; Sherman 1982; Smith 1979; Steege and Söll 1979). The aminoacyl-tRNAs involved in suppression of point mutations are called missense, nonsense, and frameshift suppressors. Nonsense suppressors are further classified as amber, ochre, and opal when they suppress UAG, UAA, and UGA codons, respectively. Even though our understanding of the occurrence, structure, and function of suppressor tRNAs in mammalian cells is largely just beginning to emerge, it would seem that our interpretation of the role of suppressor tRNAs in mammalian cells may have to be altered from the classical viewpoint. That is, in microorganisms, suppressor tRNAs have largely been thought of as providing a mechanism of correcting or reversing deleterious mutations. It appears that suppressor tRNAs, when they occur in mammalian cells, have specialized functions and are not present in order to reverse the effect of deleterious mutations.

Since our knowledge is most advanced about nonsense suppression in mammalian cells (Celis and Piper 1981; Hatfield 1985; Valle and Morch 1988; Hatfield et al. 1989), the review begins with this group of suppressors. It then focuses on ribosomal frameshifting, and subsequently, on missense suppression.

\footnotetext{
${ }^{1}$ Laboratory of Experimental Carcinogenesis, National Cancer Institute, National Institutes of Health, Bethesda, MD 20892, USA

${ }^{2}$ Department of Pathology, Northwestern University Medical School, Chicago, IL 60611, USA

${ }^{3}$ Laboratory of Molecular Virology and Carcinogenesis, Bionetics Research Inc., Basic Research Program, National Cancer Institute-Frederick Center Research Facility, Frederick, MD 21701. USA
} 


\section{B. Suppression of Nonsense Codons}

\section{Naturally Occurring Nonsense Suppressor tRNAs}

A naturally occurring nonsense suppressor tRNA is defined as any isoacceptor which exists naturally in a tRNA population and is capable of suppressing a stop codon in protein synthesis. Seven tRNAs have been shown to serve as suppressor tRNAs in mammalian cells. Four of these tRNAs are amber suppressors, which occur in three different amino acid families, and three are opal suppressors, which occur in two different amino acid families. One of the amber suppressors is tyrosine tRNA (Shindo-Okada et al. 1985), another is glutamine tRNA (Feng et al. 1989a; Kuchino et al. 1987; Yoshinaka et al. 1985a, b) and the third and fourth are leucine tRNAs (Valle et al. 1987). The opal suppressors are tryptophan tRNA (Geller and Rich 1980) and two serine tRNAs (Diamond et al. 1981; Hatfield et al. 1982a). The serine tRNAs have recently been shown to form selenocysteyl-tRNA $^{\text {Ser }}$ (Lee et al. 1989b). The tRNA ${ }^{\text {Gln }}$ occurs in both an undermodified and fully modified form (Kuchino et al. 1987), while the leucine tRNAs are major isoacceptors found in calf liver (Valle et al. 1987). The primary role of each of the amber suppressors and of the tryptophan suppressor is to translate codons within the corresponding amino acid families. The opal suppressor serine tRNAs apparently have two major functions (Lee et al. 1989b); (1) to serve as a carrier molecule for the biosynthesis of selenocysteine; and (2) to donate selenocysteine directly to protein in response to a specific UGA codon. The latter proposal for a function of the opal suppressor serine tRNAs is based on the observation that the glutathione peroxidase gene from a variety of mammalian sources contains a TGA codon in an open-reading frame, which corresponds to a selenocysteine moiety at the active site of the protein product (Chambers et al. 1986; Mullenbach et al. 1987, 1988; Reddy et al. 1988; Sukenaka et al. 1987). A naturally occurring ochre suppressor has not been described thus far in higher eukaryotes, although there is recent evidence that ochre suppressors may occur naturally in mammalian cells (see Sect. B.I.2). Additional characteristics of each of the nonsense suppressors identified in mammalian cells are given below.

\section{Amber Suppressor tRNAs}

Tyrosine tRNA. Tyrosine tRNA is mammalian cells normally contains a hypermodified nucleotide in the wobble or 5 ' position of its anticodon designated as Queuine, or Q base. Lack of Q base in the anticodon of tRNA ${ }^{\mathrm{Tyr}}$ results in the undermodified tRNA misreading the termination codon, UAG, in protein synthesis, whereas the $\mathrm{Q}$ containing tyrosine tRNA does not serve as a suppressor. This very important observation was first reported for a Drosophila tRNA $^{\text {Tyr }}$ which lacked Q base (Bienz and Kubli 1981). Tyrosine tRNA $\mathrm{Q}^{-}$from mammalian cells is also capable of suppressing UAG in protein synthesis. Shindo-Okada et al. (1985) isolated tRNA ${ }^{\mathrm{Tyr}} \mathrm{Q}^{-}$from mouse tumor cells in 
culture and have coinjected this tRNA and tobacco mosiac viral (TMV) RNA into Xenopus oocytes. TMV-RNA contains a UAG termination codon which results in expression of a $180 \mathrm{~K}$ readthrough protein when the stop codon is suppressed (Pelham 1978). The mouse tRNA ${ }^{\mathrm{Tyr}}$ supported synthesis of the viral $180 \mathrm{~K}$ readthrough protein (Shindo-Okada et al. 1985). It should be noted that tyrosine tRNA containing 6-thioqueuine was a more efficient suppressor of the TMV-RNA UAG termination codon than the tyrosine tRNA lacking $Q$ base (Shindo-Okada et al. 1985).

The structures of tyrosine tRNAs which suppress UAG codons have been determined from several higher eucaryotes, including Drosophila (Bienz and Kubli 1981; Suter et al. 1986), A. pernyi (Feng et al. 1986), tobacco plant (Beier et al. 1984a), wheat germ (Beier et al. 1984b), wheat leaves (Beier et al. 1984b), and lupin seeds (Barciszewski et al. 1985). The only difference in the sequence of the suppressor and nonsuppressor species is in the presence or absence of $\mathrm{Q}$ base in the wobble position of the anticodon. Each suppressor species lacks $\mathrm{Q}$ base. These studies show that the molecular basis for suppressor activity of tyrosine tRNA is the substitution of $\mathrm{G}$ for $\mathrm{Q}$ in the wobble position of the anticodon. Studies involving the role of undermodified tRNAs in the expression of certain proteins demonstrate unequivocally that the extent of base modification on $t R N A$ regulates the expression of specific proteins at the level of translation.

The nature of the interaction between the $\mathrm{G} \psi \mathrm{A}$ anticodon in tRNA ${ }^{\mathrm{Tyr}}$ and the UAG termination codon is not understood. G:G base pairings are not permitted in the wobble hypothesis (Crick 1966). The $G$ in the anticodon must participate, however, in the recognition process, since the $\mathrm{G} \psi \mathrm{A}$ anticodon does not translate UAA codons (Beier et al. 1984b). Beier et al. (1984b) suggested that the $\mathrm{G}$ in the anticodon may interact with the $\mathrm{G}$ in $\mathrm{UAG}$ in the syn conformation (Jank et al. 1977; Topal and Fresco 1976). Further discussion of the possible interaction of $\mathrm{G}$ in the $5^{\prime}$ position of the tyrosine tRNA anticodon and the $3^{\prime}$ position of the UAG termination codon may be found in a review by Valle and Morch (1988). The $\psi$ in the middle position of the anticodon, which is unique to tRNA ${ }^{\mathrm{Tyr}}$ of eucaryotes (Sprinzl et al. 1987), apparently also participates in the ability of the Q-deficient isoacceptor to read UAG codons. Johnson and Abelson (1983) have shown that changing the $\psi$ to $U$ in yeast tRNA ${ }^{\text {Tyr }}$ results in a loss of suppressor activity. Thus, the $\psi$ :A base pairing in the middle position probably forms a more stable anticodon: codon complex than the U:A base pairing (Ward and Reich 1968) which may be required for suppression of the UAG termination codon (Barciszewski et al. 1985; Beier et al. 1984a, b; Bienz and Kubli 1981; Feng et al. 1986). The coding properties of Q-containing and Q-lacking Asn-, Asp-, and His-tRNAs which, unlike Tyr-tRNA, contain $U$ in the middle position of their anticodon, are discussed in the section on missense suppression.

Glutamine $t R N A$. Mammalian type-C viruses translate their gag and pol genes in the same reading frame (Shinnick et al. 1981). The gag-pol fusion protein arises, therefore, from suppression of the UAG termination codon at the $3^{\prime}$ end of the 
gag gene, as first demonstrated by Philipson et al. (1978). These investigators added a yeast amber suppressor to reticulocyte lysates programmed with murine Moloney leukemia viral mRNA, which demonstrated an enhancement in the expression of the fusion protein (Philipson et al. 1978). The amino acid which occurs at the readthrough site in vivo was identified by isolating the protease from murine Moloney leukemia virus (MuLV) and determining its aminoterminal sequence (Yoshinaka et al. 1985a). Alignment of these amino acid sequences with the viral DNA sequence (Shinnick et al. 1981) demonstrated that the first four amino acids are encoded at the $3^{\prime}$ end of the gag gene. The amino acid at the fifth position is glutamine, which is coded by the gag termination codon. Similarly, feline leukemia virus contains a glutamine residue at position five in its protease, which corresponds to the gag termination codon (Yoshinake et al. 1985b). These results demonstrate that a glutamine isoacceptor serves as a naturally occurring amber suppressor in mammalian cells.

The glutamine tRNA involved in expression of the gag-pol fusion protein in MuLV has been examined by Kuchino et al. (1987) and by Feng et al. (1989a). Kuchino and collaborators reported that a minor CAA glutamine isoacceptor representing $1-2 \%$ of the total glutamine tRNA population was induced many fold in MuLV-infected NIH-3T3 cells, and that this isoacceptor is able to suppress the UAG codon in TMV RNA in vitro. In addition, these investigators observed that treatment of both MuLV- (Kuchino et al. 1988) and HIV-infected (Müller et al. 1988) cells with avarol, which is a sesquiterpernoid hydroquinone, results in a substantial reduction in the level of the glutamine suppressor tRNA, which parallels inhibition of viral expression. In contrast, Feng et al. (1989a) found that the levels of glutamine tRNA are the same in MuLV infected and uninfected cells and that the distribution of the glutamine CAG and CAA decoding isoacceptors is unchanged following virus infection. At present, the reason for the discrepancy in the results obtained by the two laboratories is not clear. Using a rabbit reticulocyte lysate programmed with a MuLV-mRNA containing sequences from the gag and pol regions, Feng et al. (1989a) also found that equivalent amounts of tRNA from MuLV-infected and uninfected NIH-3T3 cells stimulate readthrough suppression to the same extent. Similarly, Panganiban (1988) has shown that transfection of a construct, containing a portion of the MuLV gag-pol region (including the UAG codon) fused to lacZ into several vertebrate cell types, leads to an amount of $\beta$-galactosidase production which represents about $10 \%$ suppression; use of MuLV-infected cells did not enhance enzyme synthesis. Thus, the in vitro and in vivo results demonstrate that suppression of the MuLV amber codon is not dependent on potential virusinduced qualitative or quantitative modification of suppressor tRNA.

Kuchino et al.(1987) also isolated and sequenced two glutamine tRNAs from mouse liver. The anticodon of the major isoacceptor was CUG and that of the minor isoacceptor was UmUG. The primary sequence of these tRNAs differed from each other in the wobble position of the anticodon and at positions 4 and 68 of the acceptor stem. Mouse liver contained two additional glutamine tRNAs which differed from those described above by a single hypomodification at 


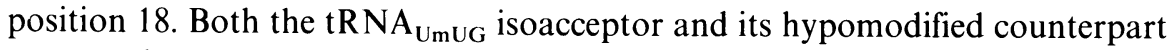
promoted suppression of the UAG codon involved in the expression of the $180 \mathrm{kDa}$ readthrough protein in TMV RNA while the $\mathrm{TRNA}_{\mathrm{CUG}}$ did not (Kuchino et al. 1987). The sequence of the proposed glutamine suppressor is shown in Fig. $1 \mathrm{~A}$.

It should be noted that interaction of glutamine UmUG anticodon and the UAG codon requires a wobble in the first and third position of the anticodon. Wobble of the $\mathrm{G}$ in the third position of the anticodon with $\mathrm{U}$ in the first position of the codon is not unique to the mouse glutamine tRNA. Pure et al. (1985) have reported that the yeast glutamine tRNA which reads CAA is also capable, when

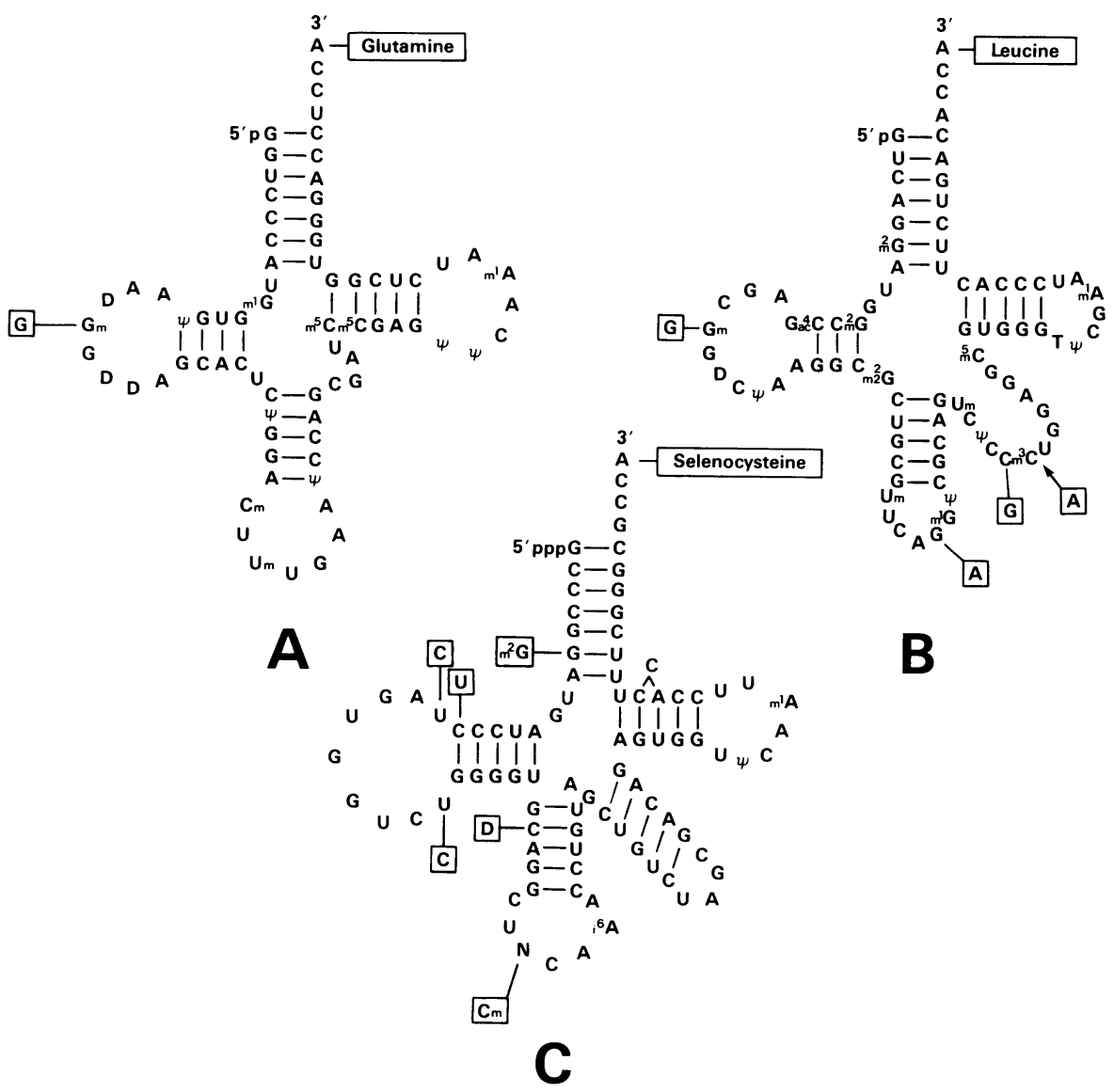

Fig. 1. Primary sequences of nonsense suppressor tRNAs isolated from mammalian sources. The sequence of the amber suppressor glutamine $\mathrm{RNA}_{U \mathrm{UmG}}$ and its hypomodified counterpart from mouse liver (Kuchino et al. 1987) are shown in $A$, of the amber suppressor leucine

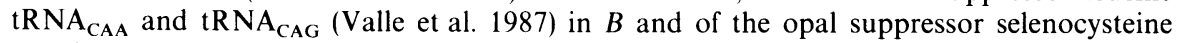
tRNA $_{\text {CmCA }}$ and tRNA NCA (Diamond et al. 1981; Hatfield et al. 1982a and see text) in C. Boxed nucleotides with a line show base differences and the arrow in the leucine tRNA shows the presence of an extra nucleotide 
present in high copy number, of weakly suppressing UAA. In addition, the yeast glutamine tRNA which reads CAG is also capable, in normal concentrations and under normal physiological conditions, of suppressing UAG (Lin et al. 1986; Weiss and Friedberg 1986; Weiss et al. 1987b). Valle et al. (1987) have shown that a calf liver leucine $t R N A$ with the anticodon CAG can suppress UAG codons (see below). Hence, the latter three tRNAs must also include a wobble of the $G$ in the third position of the anticodon to recognize $U$ in the first position of the codon. The unique feature, however, in the mouse glutamine suppressor tRNA is that a wobble is required in the first and third position of the anticodon in order to translate the UAG codon. As noted below, the interaction between a calf liver leucine anticodon and the UAG codon provide an even more intriguing example of codon: anticodon mismatching.

Leucine tRNAs. Valle et al. (1987) observed the presence of two novel amber suppressor leucine $t R N A s$ in mammalian cells. These investigators fractionated total calf liver tRNA on a BD-cellulose column and observed that some of the eluted fractions were capable of suppressing the UAG termination codon in TMV RNA and in beet necrotic yellow vein virus (BNYVV) RNA in a cell-free protein synthesis system. They carefully monitored the suppressor activity through subsequent purification steps which included one-dimensional and then two-dimensional polyacrylamide gel electrophoresis. To rule out the possibility that tRNA ${ }^{\mathrm{Tyr}}$ was responsible for the observed suppressor activity as had been demonstrated in numerous other higher eukaryotic systems (see above), two tRNA $^{\text {Tyr }}$ species were purified and partially sequenced. Both isoacceptors contained $\mathrm{Q}$ base in their anticodon and neither promoted synthesis of the TMV readthrough protein. The two species which suppressed UAG were sequenced and found to be leucine isoacceptors; they are, therefore, novel amber suppressors. Valle et al. (1987) also showed that leucine $\mathrm{tRNA}_{\mathrm{IAG}}$ from bovine mammary tissue (Vasilieva et al. 1984) did not suppress the UAG codon in TMV RNA and in BNYVV RNA, but that leucine $\mathrm{RNAA}_{\mathrm{CAG}}$ from bovine mammary tissue, which differs in its primary structure ${ }_{\mathrm{x}}$ from the calf liver suppressor (Tukalo et al. 1980), did promote readthrough. The structures of the leucine suppressors (Valle et al. 1987) are shown in Fig. 1B.

The anticodons in the leucine suppressor tRNAs are CAG and CAA. Neither anticodon can, according to the wobble hypothesis (Crick 1966), base pair with the middle position of UAG. The $\mathrm{G}$ in the $3^{\prime}$ position of the CAG anticodon must wobble to read $U$. As noted above in the section on the glutamine amber suppressor, wobble in the third position of the anticodon has been reported for other suppressor tRNAs. The CAA anticodon can base pair with UAG in the first and third positions. A more detailed discussion of the possible anticodon: codon interactions between these leucine amber suppressor tRNAs and UAG is given by Valle et al. (1987). It is interesting to note that each of the suppressor tRNAs which are dependent on wobble in the $3^{\prime}$ position of the anticodon for recognition of the nonsense codon lack a highly modified base in the $3^{\prime}$ position adjacent to the anticodon. Numerous tRNAs contain a highly modified base in this position 
(Sprinzl et al. 1987) and its role may therefore be, at least in part, to restrict wobble. An excellent review on modified bases in TRNA, including those within the anticodon loop, and on the role of modified bases in tRNA has been recently published (Björk et al. 1987).

\section{Ochre Suppressor $t R N A s$}

The naturally occurring UAG termination codon at the end of the gag gene in MuLV (Feng et al. 1989b) and at the end of the $130 \mathrm{~K}$ protein in TMV (Ishikawa et al. 1986), as well as the naturally occurring UGA termination codon in an open reading frame in Sinbis virus (Lin and Rice 1989), have been altered to a UAA termination codon. Introduction of each mutated virus into the corresponding host cell results in formation of mature virus. Furthermore, in vitro examination of TMV expression (Ishikawa et al. 1986) and of MuLV expression (Feng et al. 1989) shows that readthrough of the mutated virus occurs without supplementation of rabbit reticulocyte lysates with exogenous tRNA. These studies demonstrate that mammalian cells (as well as tobacco cells) contain a tRNA or tRNAs capable of reading an ochre termination codon. It is of considerable significance to identify the isoacceptor or isoacceptors which suppress UAA termination codons in higher eukaryotes.

It should also be noted that the yeast glutamine tRNA which reads CAA has been shown in high copy number to suppress UAA termination codons (Pure et al. 1985).

\section{Opal Suppressor $t R N A s$}

Tryptophan $t R N A$. A tryptophan tRNA which was isolated from rabbit reticulocytes has been shown to suppress the UGA termination codon in rabbit $\beta$-globin mRNA by Geller and Rich (1980). Evidence was presented that the readthrough protein of $\beta$-globin occurs naturally in rabbit reticulocytes and that Trp-tRNA is a likely candidate to carry out this suppression. The rabbit reticulocyte tRNA ${ }^{\mathrm{Trp}}$ suppressor has not been sequenced to date. It should be noted that a minor serine tRNA which reads UGA in protein synthesis also occurs in rabbit reticulocytes (Hatfield 1985; Hatfield et al. 1979, 1982b; Hatfield and Rice 1986) and this tRNA must also be considered as a potential candidate to account for the presence of $\beta$-globin readthrough protein. Antibodies have been generated specifically against the readthrough portion of this protein and the readthrough protein has been purified from rabbit reticulocytes in order to determine the amino acid at the readthrough site (Hatfield et al. 1988).

Serine tRNAs (Selenocysteine $t R N A^{\mathrm{Ser}}$ ). Two minor serine tRNAs have been shown to suppress UGA in protein synthesis (Diamond et al. 1981; Hatfield et al. 1982a). The primary sequences of these tRNAs from bovine liver (Dimond et al. 1981; Hatfield et al. 1982a) are shown in Fig. 1C. They are designated NCA and $\mathrm{CmCA}$ on the basis of their anticodon sequences. $\mathrm{N}$ is an unknown base but is probably a modified $U$ (Kato et al. 1983). The corresponding serine tRNAs from 
mouse and human tissues have also been sequenced (Kato et al. 1983) and are very similar to those shown in the figure. The genes encoding these serine tRNAs have been isolated and sequenced from human (O'Neill et al. 1985), rabbit (Pratt et al. 1985), chicken (Hatfield et al. 1983), and Xenopus (Lee et al. 1989a) genomes. The genes are identical in sequence, with the exception that the human and rabbit genes contain a $\mathrm{T}$ at position 11 , while those of chicken and Xenopus contain a $\mathrm{C}$ at this position. These genes contain a TCA sequence corresponding to the anticodon of the gene product, demonstrating unequivocally that higher eukaryotes contain tRNAs capable of reading a termination codon in their genomes. Interestingly, these isoacceptors also occur as phosphoseryl-tRNA (Hatfield et al. 1982a; Mizutani and Hoshimoto 1984) and as selenocysteyltRNA ${ }^{\text {Ser }}$ (Lee et al. 1989b) as is further discussed below.

It is interesting to note that the gene for these tRNAs occurs in single copy in the genomes of higher vertebrates (Hatfield 1985; Hatfield et al. 1983; O'Neill et al. 1985; Pratt et al. 1985) and that the two gene products contain several pyrimidine transitions in the $5^{\prime}$ half of their molecules, including one in their anticodons (Diamond et al. 1981; Hatfield et al. 1982a). These pyrimidine transitions, therefore, must arise posttranscriptionally. The human (O'Neill et al. 1985) and rabbit genomes (Pratt et al. 1985) also contain a pseudogene corresponding to the serine tRNA gene. The gene and pseudogene have been mapped to human chromosomes 19 and 22, respectively (McBride et al. 1987). Restriction analysis of DNAs isolated from the white blood cells of ten different humans revealed that the opal suppressor tRNA gene contains a Sall restriction fragment-length polymorphism (McBride et al. 1987).

The minor opal suppressor serine tRNAs are aminoacylated with serine by seryl-tRNA synthetase (Mizutani et al. 1984) and then phosphorylated on their serine moiety to form phosphoseryl-tRNA (Hatfield et al. 1982a; Mizutani and Hashimoto 1984). They have an unique pathway of biosynthesis (Lee et al. 1987) in that they are transcribed, unlike other tRNAs, beginning at the first nucleotide inside their coding sequence, and thus they do not have a $5^{\prime}$ leader sequence. The $3^{\prime}$ trailer sequence, on the other hand, is cleaved by the $3^{\prime}$ processing enzyme (Lee et al. 1987). The $5^{\prime}$ triphosphate on the initial nucleotide of the mature tRNA is transported from the nucleus to the cytoplasm of Xenopus oocytes and remains intact in the cytoplasm, suggesting that the triphosphate may have a role in the function of these tRNAs. Their kinetics of transport are very similar to those of other tRNAs (Lee et al. 1987). In vivo transcription of the Xenopus gene is regulated by several upstream sites, including a TATA box and a GC-rich region at about -30 (Lee et al. 1989a).

The observation that a minor seryl-tRNA from chicken liver was phosphorylated on its serine moeity in the presence of ATP and a kinase preparation from estrogen-induced rooster liver was first described by Mäenpää and Bernfield (1970). At the same time, a minor serine isoacceptor from bovine liver and brain, and from chicken liver, was found to specifically recognize the nonsense codon, UGA (Hatfield and Portugal 1970) in a ribosomal binding assay (Nirenberg and Leder 1964). Subsequently, Sharp and Stewart (1977) demonstrated that a minor 
seryl-tRNA from bovine mammary tissue formed phosphoseryl-tRNA in the presence of ATP and a kinase preparation from the homologous tissue. It was not until 1982, however, that the minor seryl-tRNA which recognized UGA in a ribosomal binding assay and the minor seryl-tRNA which was phosphorylated on its serine moiety were demonstrated to be the same molecule (Hatfield et al. 1982a). The report that the minor seryl-tRNA from rooster liver did not recognize UGA in a ribosomal binding assay (Mäenpää 1972) was not substantiated by earlier (Hatfield and Portugal 1970) and subsequent studies (Hatfield 1985; Hatfield et al. 1982a). The kinase which phosphorylates these isoacceptors has been purified from bovine liver (Mizutani and Hashimoto 1984). Its molecular weight is approximately $140 \mathrm{kDa}$; the $\mathrm{K}_{\mathrm{m}}$ values for ATP and the opal suppressor tRNA are $2 \mathrm{mM}$ and $21 \mathrm{nM}$, respectively. The association constants between the opal suppressor serine tRNA and an oligonucleotide consisting of $\mathrm{UGA}_{\mathbf{x}}$ (where $\mathrm{x}$ designates an unknown number of $\mathrm{A}$ residues) and between the mammlian release factor and $\mathrm{UGA}_{\mathrm{x}}$ have been examined (Mizutani and Hitaka 1988). A $\mathrm{K}_{\mathrm{a}}$ value of $8 \times 10^{3} \mathrm{M}^{-1}$ was observed for the tRNA and UGA and of 1.26 $\times 10^{6} \mathrm{M}^{-1}$ for the release factor and UGA which led Mizutani and Hitaka (1988) to conclude that the opal suppressor tRNA does not function to suppress UGA termination codons, but functions to suppress UGA codons which may favor readthrough.

Phosphoseryl-tRNA can donate its phosphate to rabbit globin in protein synthesis (Mizutani and Tachibana 1986), but the amount of incorporation was low and the site of incorporation was not established. The possibility that phosphoseryl-tRNA is an intermediate in the metabolic pathway from 3phosphoglycerate to glycine (Mäenpää and Bernfield 1970) has been ruled out by Mizutani et al. (1988). Other possible roles of phosphoseryl-tRNA ${ }^{\text {Ser }}$ have been suggested by Stewart and Sharp (1984). However, the major role of phosphoseryltRNA may be to serve as a intermediate in the biosynthesis of selenocysteyltRNA ${ }^{\text {Ser }}$ (see below).

The recent observation that the minor serine tRNA which reads UGA in protein synthesis and is phosphorylated on its serine moiety to form phosphoseryl-tRNA also exists as selenocysteyl-tRNA (Lee et al. 1989b) strongly suggests that this tRNA has at least two important cellular functions: (1) to serve as a carrier molecule for the biosynthesis of selenocysteine; and (2) to donate selenocysteine directly to protein in response to specialized UGA codons which code for selenocysteine (Lee et al. 1989b). It should be noted in this connection that a TGA codon occurs in mouse (Chambers et al. 1986; Mullenbach et al. 1988), human (Mullenbach 1987, 1988; Sukenaka et al. 1987), bovine (Mullenbach et al. 1988), and rat glutathione peroxidase genes (Reddy et al. 1988) at the position corresponding to the active site of the protein product, and that selenocysteine occurs at this site in the protein. Furthermore, the selenocysteine moiety arises from serine and selenium (Sundee and Evenson 1987). Interestingly, the glutathione peroxidase gene maps to human chromosomes 3,21, and X; the mapping data confirm that chromosome 3 is the active gene and suggest that the other loci are pseudogenes (McBride et al. 1989). 
It is important to note that selenocysteine occurs at the active site of formate dehydrogenase in $E$. coli which is coded by UGA (Zinoni et al. 1987). The occurrence of the selenocysteine moiety in formate dehydrogenase is correlated with a specific tRNA which is aminoacylated with serine (Leinfelder et al. 1988) and also forms selenocysteyl-tRNA (Leinfelder et al. 1989). Thus, the pathway of selenocysteine biosynthesis, and subsequent incorporation of selenocysteine into protein appears to be similar in mammalian (Lee et al. 1989b) and in E. coli cells (Böck and Stadtman 1988; Leinfelder et al. 1989).

The means by which UGA may code on the one hand for selenocysteine and on the other hand as a termination codon has been discussed recently by several investigators (Chambers and Harrison 1987; Engelberg-Kula and SchoulakerSchwarz 1988a, b; Valle and Morch 1988).

An opal suppressor tRNA gene has been isolated and sequenced from Drosophila and from a nematode, C. elegans (B.J. Lee, M. Rajagopalan, Y.S. $\mathrm{Kim}$, and D. Hatfield, unpublished data). The gene differs from that of vertebrates at a number of nucleotides, demonstrating that this gene has undergone substantial evolutionary change. The vertebrate (Hatfield 1985) and nematode genes have little homology to the corresponding selenocysteyl-tRNA gene in $E$. coli (Böck and Stadtman 1988). These observations provide evidence that the tRNA responsible for the presence of selenocysteine in protein which is coded by UGA is widespread in nature, but has undergone substantial change.

\section{Assays for Nonsense Suppressor tRNAs and Nonsense Mutations}

In Vitro. Nuclease-treated rabbit reticulocyte lysates (Jackson and Hunt 1983) and wheat germ extracts (Roberts and Paterson 1973), which are then programmed with mRNA and to which is added a suppressor TRNA, have provided a relatively simple means of identifying nonsense suppressors and of identifying nonsense mutations. Assays were devised for identifying opal and ochre suppressor tRNAs by adding rabbit globin mRNA and a suppressor tRNA to the nuclease-treated lysates, and examining the globin products on a polyacrylamide gel (Gesteland and Wills 1979). Rabbit $\beta$-globin mRNA terminates in UGA and the next termination signal is followed 22 amino acids downstream by two tandem UAA codons (Efstratiadis et al. 1977). Rabbit $\alpha$-globin mRNA terminates in UAA, and the next termination signal is 21 amino acids downstrem (Marotta et al. 1977). Since $\alpha$ - and $\beta$-globins are 141 and 146 amino acids in length, respectively, then the readthrough protein of $\beta$-globin would be expected to migrate more slowly on a polyacrylamide gel than the corresponding $\alpha$-globin readthrough protein. However, the reverse is found and the reason appears to be due to the large number of proline residues coded within the readthrough region of $\alpha$-globin mRNA (Gesteland and Wills 1979). Rabbit reticulocyte lysates are also used as an assay for amber suppressors by programming the nucleasetreated lysates with TMV RNA (Pelham 1978) or BNYVV RNA (Ziegler et al. 1985) and examining the products of protein synthesis on a polyacrylamide gel. Wheat germ extracts programmed with the same set of mRNAs as used in 
reticulocyte lysates have also been used as an assay for nonsense suppressors (Kohli et al. 1979). However, the lysate system has been more widely used.

Nonsense mutations and termination codons have been identified in viruses by assaying viral mutant or normal mRNAs in vitro in the presence of the purified suppressors from microorganisms. A series of human adenoviral mutants which synthesized a polypeptide shorter than the $30 \mathrm{kDa}$ ND1 protein were assayed for restoration of the protein in the presence of an amber and an ochre suppressor from yeast (Gesteland et al. 1977). Two amber and one ochre adenoviral ND1 mutations were identified amongst a series of suspected nonsense mutations. Similarly, an amber and on opal mutation were identified in the thymidine kinase gene of herpes simplex virus by assaying a series of mutant mRNAs for restoration of viral kinase activity (Cremer et al. 1979). In addition, the termination codon in several murine leukemia and sarcoma viral RNAs, which is at the end of the $g a g$ region, were identified as UAG by utilizing an amber suppressor tRNA from yeast (Murphy et al. 1980).

The specific response of a minor seryl-tRNA ${ }^{\text {Ser }}$ to UGA (Hatfield et al 1982a) in a ribosomal binding assay (Nirenberg and Leder 1964) has provided a simple and rapid means of identifying the occurrence of this isoacceptor in tissues and cells of higher vertebrates (Diamond et al. 1981; Hatfield and Portugal 1970; Hatfield et al. 1982a). The occurrence of potential opal suppressor tRNAs within the tRNA population of bovine liver were detected by fractionating the tRNA and then determining which fractions stimulated attachment of ${ }^{3} \mathrm{H}-\mathrm{UGA}$ to ribosomes (Hatfield 1972). The assay is based on a previous observation that the binding of a labeled trinucleotide diphosphate to ribosomes is significantly enhanced in the presence of the corresponding isoacceptor which recognizes that codon (Hatfield and Nirenberg 1971). It is interesting to note that the only tRNAs which recognized UGA specifically were the minor opal suppressor seryl-tRNAs. All other tRNAs which stimulated the attachment of ${ }^{3}$-H-UGA to ribosomes also recognized their assigned codons.

In Intact Cells. Purified suppressor tRNAs from microorganisms have been injected into cells in culture (Capeschi et al. 1977) and into Xenopus oocytes (Bienz et al. 1980, 1981) in order to identify nonsense mutations and to examine their effects on readthrough. For example, E. coli and yeast suppressors were injected into mouse L cells which were suspected of carrying a nonsense mutation in the HGPRT gene (Capecchi et al. 1977). the ochre tRNAs, but not the amber or opal, restored HGPRT activity. Thus, the mutation was identified as UAA.

An assay has been developed for quantifying suppressor activity in intact cells (Young et al. 1983). The assay is based on suppression of a natural UAG termination codon in the NSI protein of the influenza virus which extends the protein length by 20 amino acids. An amber suppressor tRNA gene (see Laski et al. 1982 and below) and the influenza virus were introduced into mammalian cells and the cells were then pulse-labeled with ${ }^{35} \mathrm{~S}$-methionine. The resulting labeled NSI protein and readthrough protein were isolated from a cell extract by immunoprecipitation, electrophoresed on a polyacrylamide gel, and the percent 
readthrough determined. The level of suppression was high (ca. $25 \%$ ) in cells in which the suppressor gene was transiently introduced, but was low (ca. $2.5 \%$ ) in cells in which the suppressor was stably integrated into the host's genome. It is not known whether the low level of suppression observed thus far in mammalian systems in which suppressors are permanently integrated is established by the cell because a higher level of readthrough would be lethal, or if higher levels can actually be tolerated. The fact that the level of suppression is ca. $3 \%$ in a number of studies involving different mammalian cell lines (Ho et al. 1986; Hudziak et al. 1982; Young et al. 1983) suggests that the host can tolerate only a low level of suppressor activity.

An in vivo assay for measuring the levels of aminoacylation of suppressor tRNA following their amplification has been developed (Ho and Kan 1987). The assay is based on the aminoacylation of the amplified suppressor tRNA in intact cells, extraction of the tRNA at low $\mathrm{pH}$, and the subsequent separation of acylated from unacylated tRNA on a polyacrylamide gel. Amber tRNA ${ }^{\text {Gln }}$, $\mathrm{tRNA}^{\mathrm{Lys}}$ and $\mathrm{tRNA}{ }^{\mathrm{Tyr}}$ suppressors, which were expressed from the corresponding amplified genes, were aminoacylated $80,40-50$, and $100 \%$, respectively. The lower levels of aminoacylation observed with $\mathrm{TRNA}^{\mathrm{Gln}}$ and $\mathrm{tRNA} \mathrm{A}^{\mathrm{Lys}}$ may be due to the effect of the altered base in the anticodon on the aminoacylation process (Ho and Kan 1987).

\section{Introduction of Nonsense Suppressor tRNA Genes into Intact Cells}

Nonsense suppressor tRNA genes which have been constructed by site specific mutagenesis, and introduced into cells of higher eukaryotes to yield active suppressors, have provided new approaches for studying nonsense suppression (Capone et al. 1985, 1986; Ho and Kan 1987; Ho et al. 1986; Hudziak et al. 1982; Laski et al. 1982,1984; Sedivy et al. 1987; Summers et al. 1983; Temple et al. 1982; Young et al. 1983). These studies provide a means of: (1) identifying and characterizing nonsense mutations; (2) quantifying suppression of nonsense codons; (3) analyzing and characterizing viral genomes through classical genetic techniques; (4) determining the long range effects of suppressor tRNAs on cells follwing the permanent insertion of the corresponding genes into the genomes of the host cell; and (5) determining whether the introduction of suppressor tRNAs into cells may provide a basis for gene therapy experiments involving diseases which result from nonsense mutations. Kan and collaborators have designed experiments specifically addressing the use of nonsense suppressor tRNAs in gene therapy (Ho and Kan 1987; Ho et al. 1986; Temple et al. 1982). An ambersuppressor tRNA ${ }^{\text {Lys }}$ gene (Temple et al. 1982), and subsequently, an ambersuppressor tRNA ${ }^{\mathrm{Gln}}$ gene (Ho et al. 1986), and mRNA from a patient with thalassemia carrying a UAG mutation (AAG $\rightarrow \mathrm{UAG}$ ) were coinjected into Xenopus oocytes. Functional suppressors were produced which translated the amber mutation. Although these studies provide a model for gene therapy, much greater insight into the ability of suppressors to function in cells is required before 
such experiments can be undertaken. Further characterization of the tRNA ${ }^{\mathrm{Lys}}$ suppressor has shown that it functioned inefficiently as a suppressor in cells in which it has been permanently inserted, even though the gene and gene product were amplified many fold. The suppressor was poorly aminoacylated in cell lines in which it was stably introduced, which accounted for its low suppressor activity. Other concerns must also be addressed before tRNA suppressors can be used in experiments correcting nonsense mutations in human globin. It must be established whether suppressor tRNAs are efficiently expressed in erythroid cells, and if the levels of production and subsequent aminoacylation of suppressor tRNAs are adequate to suppress nonsense codons providing sufficient amounts of globin, but yet the suppressor activity is not at a level which is deleterious to the cell. Furthermore, the level of $\beta$-globin mRNA varies in thalassemia patients and often is quite low (see Bunn and Forget 1986, and references therein). Introduction of a suppressor tRNA gene into cells containing a nonsense mutation in globin mRNA has shown an enrichment in the level of the mutated mRNA (see Bunn and Forget 1986, and references therein). This observation may provide a means of increasing the level of $\beta$-globin mRNA in thalassemic patients containing a nonsense mutation.

Much of our understanding of the role and effect of suppressor tRNAs in mammalian cells is due to the studies of RajBhandary, Sharp and their collaborators (Capone et al. 1985, 1986; Hudziak et al. 1982; Laski et al. 1982, 1984; Sedivy et al. 1987; Summers et al. 1983; Young et al. 1983). A number of tRNA suppressor genes were generated by site specific mutagenesis in the anticodon of the corresponding normal gene. These suppressors include an amber (Laski et al. 1982) and an ochre (Hudziak et al. 1982) which were derived from a Xenopus laevis tyrosine tRNA gene, and an amber, ochre, and opal which were derived from a human serine tRNA gene (Capone et al. 1985). Each suppressor gene was cloned into an appropriate vector for introduction into a given mammalian cell line. A complementary set of nonsense codons was also introduced into mammalian cells to test the biological activity of the corresponding suppressor tRNAs. The nonsense codons included naturally occurring amber and ochre termination codons, encoded in different viral strains (Capone et al. 1985; Laski et al. 1982, 1984) and amber, ochre, and/or opal mutations generated in viral (Hudziak et al. 1982; Laski et al. 1984; Sedivy et al. 1987) and E. coli genes (Capone et al. 1986; Hudziak et al. 1982) and in the kanamycin resistance gene (Hudziak et al. 1982; Laski et al. 1984). An extremely useful set of mutations was prepared in an E. coli CAT gene in which the serine codon at position 27 was changed to either an amber, ochre, or opal codon (Capone et al. 1986). Cointroduction of the mutant CAT genes, other mutant $E$. coli genes, mutant viral genes, or a virus containing a naturally occurring termination codon and the corresponding suppressor tRNA has shown that the level of suppression was efficient (ranging from ca. 20-50\%) in transient systems (Capone et al. 1986; Young et al. 1983), but inefficient (ca. $3 \%$ ) in cell types in which the suppressor tRNA gene was stably integrated into the host's genome (Ho et al. 1986; Hudziak et al. 1982; Young et al. 1983). Ineffective aminoacylation of suppressor tRNAs 
may account for the poor suppressor activity in cells in which the suppressor tRNA genes are permanently inserted (Ho et al. 1986). However, whether a secondary mutation may have occurred in the suppressor tRNA gene, in the corresponding synthetase gene, or perhaps whether the low suppressor activity is due to some other reason is not known. Furthermore, it is not known if efficient suppression can be tolerated in cells in which the suppressor is stably integrated. As noted above, the observation that different suppressor tRNA genes which are stably introduced into different mammalian cell lines result thus far in suppression levels of only about $3 \%$ suggests that higher levels may be lethal to the cell.

A means of inducing high levels of suppressor activity in mammalian cells has been reported recently (Sedivy et al. 1987). An amber suppressor tRNA ${ }^{\text {Ser }}$ gene was cloned into SV40 near its origin of replication. This plasmid was cotransfected into mammalian cells with a SV40 plasmid carrying a temperature sensitive mutation in the large $\mathrm{T}$-antigen gene and cells which stably integrated both DNAs were selected. The suppressor gene was amplified by changing the cells from a nonpermissive to a permissive temperature and suppression levels of an amber codon as high as $70 \%$ were observed. This technique was used to suppress an amber mutation in the replicase gene of poliovirus which resulted in an efficient production of virus (Sedivy et al. 1987).

\section{Other Considerations}

Several termination codons have been shown to be readthrough in mammalian cells. These include the UAG stop codon in Moloney leukemia virus (Feng et al. 1989a; Kuchino et al. 1987; Philipson et al. 1978; Yoshinaka et al. 1985a) and in feline leukemia virus (Yoshinaka et al. 1985b) and the UGA stop codon in Middelburg and Sindbis viruses (Strauss et al. 1983, 1984), in rabbit $\beta$-globin mRNA (Geller and Rich 1980; Hatfield et al. 1988) and in glutathione peroxidase (Chambers et al. 1986; Mullenbach et al. 1987, 1988; Reddy et al. 1988; Sukenaka et al. 1987).

The level of suppression at a stop codon is presumably determined by the competition between the suppressor tRNA, which promotes readthrough, and the release factor, which promotes termination, for the nonsense codon. In microorganisms, the nucleotides surrounding stop codons (i.e., the nucleotide context) also play a role in the efficiency of suppression (Bossi 1983; Miller and Albertini 1983). In higher eukaryotes, the available evidence suggests that nucleotide context is not a determining factor in whether a termination codon will be suppressed, nor how efficiently it will be suppressed (Kohli and Grosjean 1981; Kubli et al. 1982; Mullenbach et al. 1988). Some stop codons occur in an open reading frame (Chambers et al. 1986; Mullenbach et al. 1987, 1988; Reddy et al. 1988; Strauss et al. 1983, 1984; Sukenaka et al. 1987) and they must be translated efficiently for expression of the resulting protein product. For, example, glutathione peroxidase activity is dependent upon efficient readthrough of a UGA codon, which corresponds to an amino acid that is translated within 
the first $30 \%$ of the protein. Mullenbach and collaborators (1988) have compared the sequences surrounding the opal codon in human, bovine, and mouse glutathione peroxidase mRNAs to those surrounding natural opal termination codons in a number of eukaryotic mRNAs. The translated UGA codon has $5^{\prime}$ sequences and $3^{\prime}$ sequences, which are identical to those surrounding natural UGA termination codons. Thus, the nucleotide context of the UGA codon in glutathione peroxidase does not appear to be related to the efficient translation of this codon. These investigators also compared the secondary structure of glutathione peroxidase and 12 other eucaryotic mRNAs which utilize UGA as a termination codon (Mullenbach et al. 1988). This study revealed that glutathione peroxidase mRNA may have a unique conformation in which UGA occurs in a stem that may favor readthrough. Studies from other higher eukaryotic systems also suggest that the nucleotide contexts of termination codons may not play a major role in the level of suppression in mammalian cells (Kohli and Grosjean 1981; Kubli et al. 1982; Mullenbach et al. 1988). However, more information must be obtained about the nature of the suppression process of nonsense codons in mammalian cells before we can definitively assess the effect of the codon context. The reader is also referred to an excellent review on the termination process by Valle and Morch (1988) and to additional considerations of UGA as a codon for selenocysteine and as a termination codon (Chambers and Harrison 1987; Engelberg-Kula and Schoulaker-Schwarz 1988a, b).

Nonsense mutations have also been characterized in mammals. In humans, the occurrence of nonsense mutations in $\alpha$ - and $\beta$-globin mRNA genes have been known for some time (see Baserga and Benz 1988; Bunn and Forget 1986 and references therein). Recently, a series of nonsense mutations were prepared in the human $\beta$-globin gene to study the effects of nonsense mutations on cellular accumulation of mRNA (Baserga anmd Benz 1988). Each nonsense mutation resulted in a decreased accumulation of $\beta$-globin mRNA, whereas missense mutations had no effect on the level of accumulation. Other examples of nonsense mutations identified in humans are a Trp TGG $\rightarrow$ TGA mutation in the gene for the receptors for plasma low density lipoprotein (Lenman et al. 1985), an Arg CGA $\rightarrow$ TGA mutation at codon 306 in the gene for protein $\mathrm{C}$ which is an anticoagulant serine protease (Romeo et al. 1987), a Lys AAG $\rightarrow$ TAG mutation at codon 217 in the I-antitrypsin gene (Satoh et al. 1988) and an Arg CGA $\rightarrow$ TGA mutation in the C1q B-chain (McAdam et al. 1988).

Post transcriptional generation of a stop codon in mRNA which results in the occurrence of a molecular distinct protein has been observed in mammalian cells (Chen et al. 1987; Davidson et al. 1988; Hardman et al. 1987; Higuchi et al. 1988; Powell et al. 1987). In humans, a single gene encodes apolipoprotein (apo) B-100 and apoB- 48 , where apoB- 48 is ca. $48 \%$ of the molecular weight of apoB100. A glutamine codon (CAA) at position 2153 in human apoB-100 is converted to a termination codon by a single pyrimidine transition (Powell et al. 1987). This reaction is tissue specific (Chen et al. 1987; Hardman et al. 1987; Higuchi et al. 1988; Powell et al. 1987) and is hormonally modulated in rat liver (Davidson et al. 1988). 


\section{Ribosomal Frameshifting}

Ribosomal frameshifting or frameshift suppression may operate in one of two directions to alter the reading frame. It may occur by a variety of mechanisms (Craigan and Caskey 1987; Dayhuff et al. 1986; Murgola 1989; Weiss et al. 1987a, 1988) such that the reading frame is altered in the $5^{\prime}$ direction or in the $3^{\prime}$ direction. Ribosomal frameshifting in both directions has been described in bacteria and yeast (see above references and in addition Valle and Morch 1988, and references therein). In mammalian cells, many retroviruses utilize ribosomal frameshifting in the -1 direction to align their gag and pol reading frames (Craigan and Caskey 1987; Hizi et al. 1987; Jacks and Varmus 1985; Jacks et al. 1987, 1988a, 1988b; Valle and Morch 1988). Since ribosomal frameshifting is best understood in retroviruses, we will examine this means of altering reading frames and then consider the possible involvement of tRNA.

\section{Ribosomal Frameshifting in Retroviruses}

The $g a g$ and pol genes of many retroviruses occur in different reading frames (see references in legend to Table 1 and in addition Valle and Morch 1988). Some of these retroviruses require a single frameshift event in the -1 direction, while others require two such events, one between gag-pro and one between pro-pol, both of which are in the -1 direction, to align the different reading frames for expression of the gag-pro-pol fusion protein. The ribosomal frameshift sites or suspected sites and signals in a number of vertebrate retroviruses are shown in Table 1. In additon, suspected frameshift sites and signals in the mouse intracisternal Aparticle (Mietz et al. 1987), in the nonretrovirus avian coronavirus (designated IBV; Brierley et al. 1987) and in the transposable elements in Drosophila designated gypsy (Marlor et al. 1986) and 17.6 (Saigo et al. 1984) are also shown. The number of bases in each overlap window and the number of bases from the $3^{\prime}$ end of each window are also shown. The boundaries of the frameshift windows are determined (e.g. in a retrovirus requiring a single frameshift event) by the termination codon which is read in the zero frame (at the end of the gag gene) and the first upstream termination codon in the -1 frame. Each overlap window contains one of three common consensus sequences (Jacks et al. 1988b): either A AAC, U UUA or U UUU where asparagine (AAC), leucine (UUA), or phenylalanine (UUU) are read in the zero frame.

The ribosomal frameshift sites of three of the retroviruses shown in Table 1 have been examined in detail. One occurs within the gag-pro ribosomal frameshift site in MMTV and involves the A AAC sequence (Hizi et al. 1987). The other two occur within the gag-pol ribosomal frameshift site of HIV (Jacks et al. 1988b; Wilson et al. 1988) and RSV (Jacks et al. 1988a) and both involve the U UUA sequence. The polypeptide which is expressed in vivo at the gag-pro junction in MMTV (Hizi et al. 1987) and in vitro at the gag-pol junction in HIV (Jacks et al. 1988b) and RSV (Jacks et al. 1988a) has been sequenced at the site corresponding 


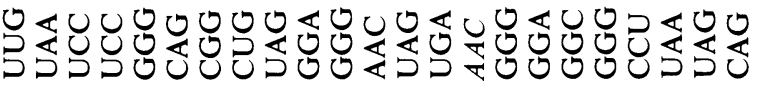

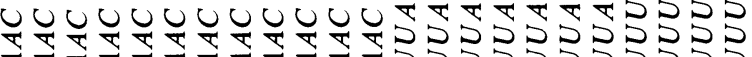

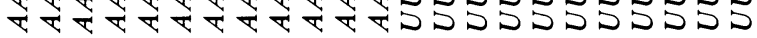

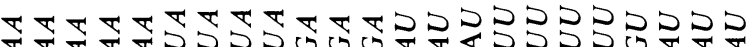

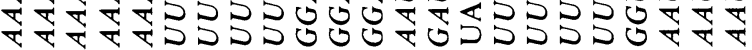

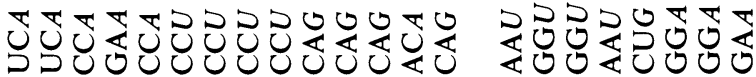

(2)
ㅇำ

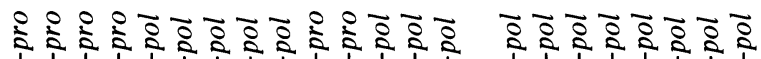

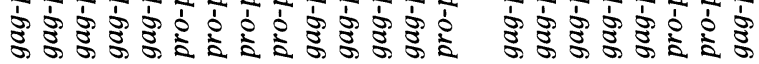

$\frac{T}{3}$

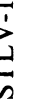

$\sum^{2}$

站

Ð

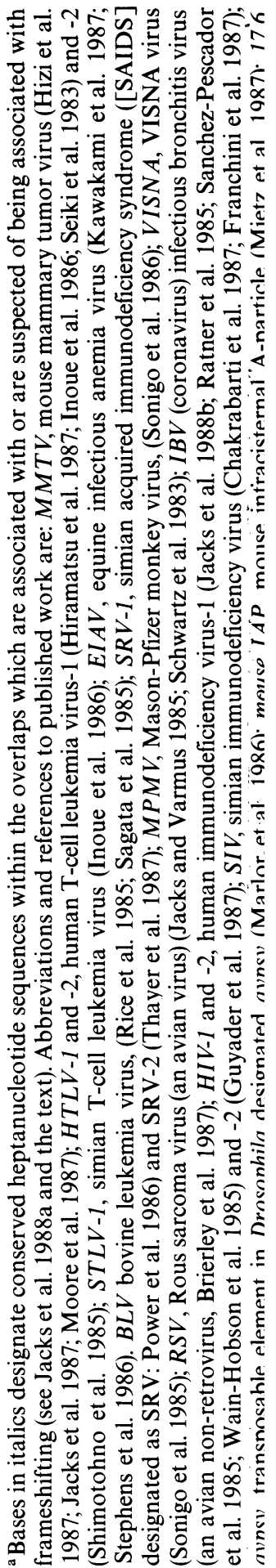


to the frameshift. In MMTV, leucine occurs at the frameshift site and is coded either by UUG in the zero frame or by CUU in the -1 frame (where $C$ is the $3^{\prime}$ base of the AAC codon in the zero frame and UU are the $5^{\prime}$ two bases of the UUG codon) (Hizi et al. 1987). In HIV, the shift occurs at a leucine residue corresponding to the UUA codon (Jacks et al. 1988b) shown in Table 1. However, both leucine and phenylalanine occur at the frameshift site in a ratio of $7: 3$, which also makes the assignment of the precise site uncertain (Jacks et al. 1988b). Arginine, which is coded by the $3^{\prime}$ base in UUA and the first two GG bases in the downstream codon, is translated in the -1 frame in HIV. In RSV, the frameshift also occurs at a leucine codon in response to the U UUA sequence (Jacks et al. 1988a). The next amino acid residue in the peptide generated from the frameshift site is isoleucine, which is read in the -1 frame; it is coded by the $3^{\prime} \mathrm{A}$ of the UUA codon and the next two downstream bases which are UA.

Sequence of the polypeptide corresponding to the frameshift site in MMTV (Hizi et al. 1987), HIV (Jacks et al. 1988a) and RSV (Jacks et al. 1988b) and generation of series of mutations within the heptanucleotide frameshift signal in RSV (Jacks et al. 1988b) and HIV (Jacks et al. 1988a; Wilson et al. 1988) and sequence of the peptide generated from the mutant RSV frameshift signal (Jacks et al. 1988b) provide insight into the mechanism by which alignment of the different reading frames occurs. Mutations constructed within the RSV heptanucleotide signal (Jacks et al. 1988b) and at most of the corresponding bases in the HIV signal (Jacks et al 1988a; Wilson et al. 1988) show that the frameshift event is inhibited by changes at each position within this region expect the $3^{\prime}$ terminal base. Changes at the $3^{\prime}$ terminal base do not inhibit frameshifting. The amino acid sequence of the peptide generated from the RSV mutant sequence, AAU UUU UA (where $U$ represents the altered base at the $3^{\prime}$ end of the frameshift signal), demonstrates that asparagine (AAU) and phenylalanine (UUU) are decoded in the zero frame and leucine (UUA) in the -1 frame (Jacks et al. 1988a). As noted above, asparagine (AAU) and leucine (UUA) are decoded in the zero frame and isoleucine (AUA) in the -1 frame in the normal RSV frameshift event (Jacks et al. 1988b). Thus, a single base change at the 3 ' end of the RSV frameshift signal results in two amino acids in the peptide generated from the mutant sequence. This observations demonstrates that alignment of the different reading frames must occur at this site and the alignment occurs by overlapping reading such that the base at the $3^{\prime}$ end of the heptanucleotide signal is decoded twice; once in the zero frame and once in the -1 frame as originally stated by Hizi et al. (1987) from their studies on sequencing the MMTV transframe protein.

Much insight into retroviral frameshifting has been obtained through the studies described above. These studies demonstrate that the shift to the -1 decoding frame occurs by overlapping reading, and not by two of three base reading, and that the frameshift occurs at the $3^{\prime}$ end of the heptanucleotide signal shown in Table 1, and not upstream of this site. These studies do not demonstrate the mechanism by which frameshifting occurs. Thus, we have learned what occurs in frameshifting (i.e., that the frameshift occurs by overlapping reading), where it occurs, but not how it occurs. In regard to a possible mechanism, Jacks et al. 
$(1987,1988 \mathrm{a}, \mathrm{b})$ have proposed a "slippage" model to account for frameshifting in which the translational machinery slips to the -1 reading frame within the heptanucleotide sequences shown in Table 1.

Mutation of the A AAA AAC sequence in the gag-pro frameshift site of HTLV-1 to A ATA TTC inhibited the frameshift event (Nam et al. 1988). This study provides direct evidence that this region which was suspected to be part of the frameshift site in HTLV-1 (Table 1) is indeed involved in the frameshift event.

The observation by Jacks et al. (1988a) that U UUA, U UUU and A AAC sequences at the end of the RSV frameshift site support effective frameshifting, while A AAA and G GGG sequences are not as effective led these investigators to propose that "only certain, specialized 'shifty' tRNAs" can participate in the frameshift event. The proposal is further supported by the observation that only three codons, UUA, UUU, and AAC, are found at the ribosomal A-site within the frameshift sites of each overlapping reading frame examined (Jacks et al. 1988a; Table 1). The possibility that the "shifty" tRNA may lack a hypermodified base in its anticodon loop is considered below.

A stem-loop region which is immediately downstream of the frameshift site in RSV is also required for efficient frameshifting (Jacks et al. 1988a). Disrupting base pairings within the stem by generating specific stem-destabilizing mutations resulted in a decrease in frameshifting, while restoring these base pairings by generating specific stem-restabilizing mutations rescued frameshifting (Jacks et al. 1988a). In HIV, there is no requirement for a downstream stem-loop effect on frameshifting and the only requirement appears to be a short RNA segment which includes the heptanucleotide frameshift signal (Wilson et al. 1988).

\section{II. tRNAs Involved in Frameshifting}

At least one, if not both, of the codons within the frameshift signals shown in Table 1 correspond to tRNAs which normally contain a hypermodified base in their anticodon loop. For example, $Q$ base occurs in Asn-tRNA (which is coded by AAU or AAC in a number of the frameshift signals) and in Asp-tRNA (which is coded by GAU in the pro-pol signal of MMTV) and Wye base occurs in PhetRNA (which is coded by UUU in a number of the frameshift signals). The coding properties of tRNAs lacking Q (Beier et al. 1984a,b; Bienz and Kubli 1981; Meir et al. 1985) or Wye base (Smith and Hatfield 1986) in their anticodon loop are altered. It seems reasonable that the frameshift event may be facilitated if the involved tRNA does not have a highly modified base in the anticodon loop; i.e., such a tRNA may be more "shifty". It is of interest to note that leucine isoacceptors (leucine is required for translation in many of the signals shown in Table 1) do not contain a hypermodified base in their anticodon loop (see Valle et al. 1987 and references therein).

The chromatographic properties of aminoacyl-tRNAs at and around the frameshift site from HIV-1, BLV and HTLV-1 infected cells and from a corresponding set of uninfected (control) cells were examined (Hatfield et al. 
1989). HIV-1 utilizes Phe-tRNA and Leu-tRNA within the gag-pol frameshift signal (Jacks et al. 1988b; Ratner et al. 1985; Sanchez-Pescador et al. 1985; WainHobson et al. 1985), while BLV (Rice et al. 1985; Sagata et al. 1985) and HTLV-1 (Hiramatsu et al. 1987; Inoue et al. 1986; Seiki et al. 1983) utilize Asn-tRNA and Lys-tRNA within the gag-pro and Asn-tRNA and Leu-tRNA within the pro-pol frameshift signals (Table 1). The data showed that virtually all of the Asn-tRNA from each set of infected cells was Q-deficient, while a greater proportion from uninfected cells contained $Q$ base (Hatfield et al. 1989). Furthermore, the data showed that virtually all of the Phe-tRNA from HIV-1 infected cells was Wyedeficient, while most of the Phe-tRNA from uninfected cells contained Wye base. The chromatographic properties of other aminoacyl-tRNAs at and around the frameshift site were not altered. It is tempting to speculate from these observations that the presence of $\mathrm{G}$ in place of the hypermodified $\mathrm{Q}$ base in the $5^{\prime}$ position of the anticodon of Asn-tRNA (and of Asp-tRNAs) (Beier et al. 1984a, b; Bienz and Kubli 1981; Meir et al. 1985; Suter et al. 1986) or of 1-methylG in place of the hypermodified Wye base in the $3^{\prime}$ position next to the anticodon of Phe-tRNA (Kuchino et al. 1982) would facilitate the frameshift event. Clearly, more space in and around the frameshift site would be created in absence of $\mathrm{Q}$ or Wye base. In addition, greater flexibility of movement of the respective tRNA anticodon might be expected in absence of a highly modified base in the anticodon loop such as is found in Leu-tRNA and in hypomodified Asn- or Phe-tRNAs.

\section{Missense Suppression and Misrecognition of Genetic Codewords}

Most mutations which occur in nature are missense. Neither missense suppressor tRNAs nor suppression of missense mutations, however, have been described thus far in mammalian cells. It is unfortunate that the large number of inborn errors in human metabolism which result from missense mutations do not appear to be approachable, at least not by our present knowledge of the utilization of aminoacyl-tRNA in protein synthesis, through gene therapy experiments involving tRNA. Even in hemoglobinopathies, where it is reasonable that a suppressor tRNA gene may be introduced selectively into red blood cell precursors rather than into the germline of intact organisms, it seems unlikely that a tRNA could be engineered to read more efficiently at a specific site to selectively correct a missense mutation. In designing gene therapy experiments involving missense suppressors in cells in culture, it would seem that several criteria must be met before attempting such experiments. (1) The mutation to be corrected should be one that corresponds to an infrequently used codeword, and hence the missense suppressor would hopefully not effect other proteins and, in addition, there would presumably be only a small amount of natural isoacceptor for the suppressor to compete with in translating the codeword. (2) The protein that is to be restored to an active state should be present in low levels and thus a missense suppressor in elevated levels could presumably completely suppress the mutation. Perhaps candidates to consider for such a possibility are 
the $\mathrm{P} 21$ ras proteins which occur in minor levels in mammalian cells and in which amino acid changes at specific positions cause the protein to become oncogenic (see Barbacid 1987 for review). Most certainly, an infrequently used codon could be generated at one of the "sensitive" sites making the protein oncogenic. Then a tRNA could be generated with an appropriate anticodon to insert a "wild-type" amino acid in response to the infrequently used codon.

Misrecognition of genetic codewords also occurs within the same amino acid family. This subtle type of misrecognition has been observed in cases where the preference of a tRNA for a codon within the same amino acid family may be changed by virtue of a base modification in the anticodon loop (Björk et al. 1987; Meir et al. 1985; Smith and Hatfield 1986; Smith et al. 1981); and an example involves a mammalian tRNA ${ }^{\text {Lys }}$ with anticodon CUU (Raba et al. 1979). The fully modified lysine isoacceptor normally reads AAG codons, while the hypomodified form which lacks $N^{6}$-threonyl-adenosine next to its anticodon in the $3^{\prime}$ position wobbles more freely to read AAA codons (Smith and Hatfield 1986; Smith et al. 1981). This form of "misreading" may favor the expression of mRNAs rich in AAA codons and must therefore be considered among the factors that are important in orchestrating the complex pattern of protein synthesis in gene expression (Smith and Hatfield 1986; Smith et al. 1985).

The effects of other hypermodified bases which occur within the tRNA anticodon loop on the coding properties of the corresponding tRNAs have also been examined. The incorporation of histidine from mammalian His-tRNAs with and without $\mathrm{Q}$ base into rabbit globin in response to the His codons, CAU and CAC, was examined in rabbit reticulocyte lysates (Smith and Hatfield 1986; Smith and McNamara 1982). No differences were observed in the preference of either tRNA for CAU or CAC. However, incorporation of histidine from Drosophila His-tRNA with and without $\mathrm{Q}$ base into turnip yellow mosaic viral coat protein in response to CAU and CAC codons manifested different patterns of incorporation (Meir et al. 1985). His-tRNA without Q base showed a strong preference for CAC codons, while that with $\mathrm{Q}$ base showed a slight preference for CAU codons. The latter studies which were examined in Xenopus oocytes provide in vivo evidence that modification of the wobble base of tRNA may result in a codon preference during translation.

A question may be raised as to whether asparagine, aspartic acid, and histidine tRNAs which are $\mathrm{Q}^{-}$can misread the corresponding XAG codewords (where $\mathrm{X}$ may be either $\mathrm{C}, \mathrm{A}$ or $\mathrm{G}$ ), and thus serve as missense suppressors, since tyrosine tRNA $\mathrm{Q}^{-}$misreads UAG codons (see Sect. B.I.1). This possibility seems highly unlikely, not only because of the competition that would exist between the $\mathrm{Q}^{-}$tRNAs and the corresponding isoacceptors which normally read XAG codewords, but also because asparagine, aspartic acid, and histidine tRNAs contain $\mathrm{U}$ in the middle position of their anticodon. Tyrosine tRNA contains $\psi$ in this position which is apparently essential for suppression to occur (see Sect. B.I.1).

Misreading of genetic codewords involving the insertion of the wrong amino acid into protein has also been observed in mammalian cells in culture following 
acute starvation for an essential amino acid (Harley et al. 1981; Parker et al. 1978; Pollard et al. 1982). The types of changes observed are consistent with the misreading of pyrimidines for purines at the $3^{\prime}$ codon position. This technique has provided a means of measuring the fidelity of translation in mammalian cells (Harley et al. 1981) and of examining the levels of mistranslation in cells before and after transformation (Pollard et al. 1982).

\section{E. Conclusion}

Our knowledge about suppressor tRNAs in mammalian cells has increased substantially in the last few years. Table $2 \mathrm{~A}$ summarizes the aminoacyl-tRNAs which suppress termination codons and Table 2B the mRNAs which are readthrough in mammalian cells. Clearly, tRNAs capable of suppressing termination codons occur naturally within the tRNA populations of mammalian cells. However, these isoacceptors apparently have specialized functions which do not include suppressing a nonsense mutation in order to correct a deleterious effect. It also seems that high levels of nonsense suppressor activity cannot be tolerated on a permanent basis by mammalian cells (Ho et al. 1986; Hudziak et al. 1982; Young et al. 1983) and thus the optimism for the use of suppressor tR NAs to correct nonsense mutations resulting in high levels of product must await further

Table 2. Natural suppression of termination codons in mammalian cells ${ }^{\mathrm{a}}$

A. Aminoacyl-tRNAs which suppress termination codons

\begin{tabular}{|c|c|c|c|c|}
\hline tRNA & Source & Anticodon & Codons read & Comments \\
\hline Tyrosine & $\begin{array}{l}\text { Mouse tumor } \\
\text { cells }\end{array}$ & $\mathrm{G} \psi \mathrm{A}$ & $\begin{array}{l}\text { UAU, UAC, } \\
\text { UAG }\end{array}$ & $\begin{array}{l}\text { Suppresses UAG stop codon } \\
\text { in TMV RNA in vitro }\end{array}$ \\
\hline Glutamine & $\begin{array}{l}\text { Mammalian } \\
\text { cells }\end{array}$ & UmUG & CAA, UAG & $\begin{array}{l}\text { Kuchino et al. }{ }^{\mathrm{c}} \text { reported that } \\
\text { this tRNA suppresses UAG } \\
\text { stop codon in TMV RNA in } \\
\text { vitro. Their report that } \\
\text { this tRNA is enriched many } \\
\text { fold in MuLV infected cells } \\
\text { was not substantiated by in } \\
\text { vivo }^{\text {d }} \text { or in vitro studies }\end{array}$ \\
\hline Leucine & $\begin{array}{l}\text { Calf liver } \\
\text { Bovine } \\
\text { mammary } \\
\text { tissue }\end{array}$ & CAG & CUG, UAG & $\begin{array}{l}\text { Suppress UAG stop codon in } \\
\text { TMV and BNYVV RNAs } \\
\text { in vitro }\end{array}$ \\
\hline Leucine & Calf liver & CAA & UUG, UAG & \\
\hline Tryptophan & $\begin{array}{l}\text { Rabbit reti- } \\
\text { culocytes }\end{array}$ & ? & UGG, UGA & $\begin{array}{l}\text { Suppresses UGA stop codon } \\
\text { in rabbit } \beta \text {-globin in vitro }\end{array}$ \\
\hline Selenocysteine & $\begin{array}{l}\text { Mammalian } \\
\text { tissues }\end{array}$ & $\mathrm{CmCA}$ & UGA & $\begin{array}{c}\text { Suppress UGA codon in rabbit } \\
\beta \text {-globin mRNA in vitro }\end{array}$ \\
\hline Selenocysteine & $\begin{array}{l}\text { Mammalain } \\
\text { tissues }\end{array}$ & $\mathrm{NCA}$ & UGA & $\begin{array}{l}\text { Form phosphoseryl-tRNA } A^{\mathrm{i}, \mathrm{j}} \\
\text { and selenocysteyl-tRNA }\end{array}$ \\
\hline
\end{tabular}


Table 2. (Continued)

B. mRNAs which are suppressed

\begin{tabular}{|c|c|c|}
\hline mRNA & Codon & Aminoacyl \\
\hline $\begin{array}{l}\text { Glutathione } \\
\text { Peroxidase }\end{array}$ & UGA & $\begin{array}{r}\text { Selenocyste } \\
\text { (see text) }\end{array}$ \\
\hline $\begin{array}{l}\text { Rabbit } \\
\quad \beta \text {-globin }\end{array}$ & UGA & ? \\
\hline $\begin{array}{l}\text { Sindbis and } \\
\text { Middelburg } \\
\text { viruses }\end{array}$ & UGA & ? \\
\hline $\begin{array}{l}\text { Moloney, feline } \\
\text { and AKR } \\
\text { leukemia viruses }\end{array}$ & UAG & Glutamine \\
\hline
\end{tabular}

Moloney leukemia UAA, UGA ?
virus

Sindbis virus UAA ?

TMV UAA

DNA from human ${ }^{1, \mathrm{~m}, \mathrm{n}}$, mouse $^{1, \mathrm{o}}$ bovine ${ }^{1}$ and rat $^{\mathrm{p}}$ sources has been sequenced and a UGA codon occurs at the active site of the gene product which corresponds to a selenocysteine moiety

Readthrough protein occurs in rabbit reticulocytes ${ }^{\mathrm{g}, \mathrm{q}}$

These viruses contain a UGA codon in an open reading frame ${ }^{\mathrm{r} . \mathrm{s}}$

The amino acid at the stop codon in gag-pol fusion protein in MuLV and feline $\mathrm{LV}$ is $\mathrm{Gln}^{\mathrm{t}, \mathrm{u}}$, but it has not been determined in $\mathrm{AKR}^{\mathrm{v}}$

The UAG stop codon at the end of the gag gene has been changed to UAA and UGA and both codons are suppressed intracellularly as well as in vitrow

The UGA codon in an open reading frame of this virus has been changed to UAA and it is suppressed intracellularly ${ }^{x}$

The UAG codon at the end of the $130 \mathrm{~K}$ protein was changed to UAA and it is suppressed in vivo and in vitro ${ }^{y}$

\footnotetext{
${ }^{a}$ References to original work in the table are indicated by a letter and are as follows: ${ }^{b}$ ShindoOkada et al. $1985 ;{ }^{\mathrm{c}} \mathrm{Kuchino}$ et al. $1987 ;{ }^{\mathrm{d}}$ Panganiban $1988 ;{ }^{\mathrm{e}} \mathrm{Feng}$ et al. $1989 \mathrm{a} ;{ }^{\mathrm{f}}$ Valle et al. 1987; ${ }^{8}$ Geller and Rich 1980; ${ }^{\mathrm{h}}$ Diamond et al. 1981; ${ }^{\mathrm{i}}$ Hatfield et al. 1982a; ${ }^{\mathrm{j}}$ Mizutani and Hashimoto 1984; ${ }^{\mathrm{k}}$ Lee et al. 1989b; 'Mullenbach et al. 1988; ${ }^{\mathrm{m}}$ Mullenbach et al. 1987; ${ }^{\mathrm{n}}$ Sukenaka et al. $1987 ;{ }^{\circ}$ Chambers et al. $1986 ;{ }^{\mathrm{p}}$ Reddy et al. $1988 ;{ }^{\mathrm{q}}$ Hatfield et al. $1988 ;{ }^{\mathrm{r}, \mathrm{s}}$ Strauss et al. 1983, 1984; ${ }^{\text {t, }}$ Yoshinaka et al. 1985a, b; ' Herr 1984; ${ }^{\text {w}}$ Feng et al. 1988b; ${ }^{\mathrm{x}}$ Lin and Rice 1989; and 'Ishikana et al. 1986.
}

experimentation. An important area for further study in the field of nonsense suppression is the reason why some termination codons are readthrough, while others are not.

Another area for possible scientific development is in the field of missense suppression, since so little is known about the occurrence and role of missense suppressors in mammalian cells. A summary of the possible ribosomal frameshift 
sites in several of the retroviruses which have been sequenced are shown in Table 1 (see also Jacks et al. 1988a). A question was raised whether one or more of the isoacceptors utilized at the "slippage site" may lack a hypermodified base in its anticodon loop to facilitate the frameshift event. If alteration of a tRNA is required by some viruses for ribosomal frameshifting, then converting these tRNAs to the fully modified form may provide an avenue for inhibiting viral expression (Hatfield 1985). Suppression of expression of viral replicative enzymes in cells infected with HIVs or HTLVs by these or other means would be of considerable therapeutic value.

Acknowledgements. The authors express their sincere appreciation to Drs. Anne-Lise Haenni, Rosaura P.C. Valle, Marie-Dominique Morch, and Eric Kubli for their critical review and helpful suggestions regarding the sections of the manuscript dealing with nonsense suppression and to the many individuals who so generously provided us with preprints and with other data prior to publication. This work was sponsored in part by NCI, DHHS under contract No. N01-CO-74101 with BRI.

\section{References}

Barbacid M (1987) ras genes. Annu Rev Biochem 56:779-827

Barciszewski J, Barciszewski M, Suter B, Kubli E (1985) Plant tRNA suppressors: in vivo readthrough properties and nucleotide sequence of yellow lupin seeds tRNA ${ }^{\mathrm{Tyr}}$. Plant Sci 40:193-196

Baserga SJ, Benz EJ Jr (1988) Nonsense mutations in the human beta-globin gene affect mRNA metabolism. Proc Natl Acad Sci USA 85:2056-2060

Beier H, Barciszewski M, Krupp G, Mitnacht R, Gross HJ (1984a) UAG readthrough during TMV RNA translation: isolation and sequence of two tRNAs ${ }^{\text {Tyr }}$ with suppressor activity from tobacco plants. EMBO J 3:351-356

Beier H, Barciszewski M, Sickinger H-D (1984b) The molecular basis for the differential translation of TMV RNA in tobacco protoplasts and wheat germ extracts. EMBO J 3:1091-1096

Bienz M, Kubli E (1981) Wild-type tRNA ${ }^{\text {Tyr }} / \mathrm{G}$ reads the TMV RNA stop codon, but Q basemodified tRNA ${ }^{\mathrm{Tyr}} / \mathrm{Q}$ does not. Nature $294: 188-190$

Bienz M, Kubli E, Kohli J, de Henau S, Grosjean H (1980) Nonsense suppression in eukaryotes: the use of the Xenopus oocyte as an in vivo assay system. Nucleic Acids Research 8:5169-5178

Bienz M, Kubli E, Kohli J, de Henau S, Huez G, Marbaix G, Grosjean H (1981) Usage of three termination codons in a single eukaryotic cell, the Xenopus oocyte, Nucleic Acids Research 9:3835-3850

Björk GR, Erickson JU, Gustafsson CED, Hagervall TG, Jönsson YH, Wilkström PM (1987) Transfer RNA Modification. Annu Rev Biochem 56:263-287

Böck A, Stadtman TC (1988) Selenocysteine, a highly specific component of certain enzymes, is incorporated by a UGA-directed co-translational mechanism. Biofactors 1:245-250

Bossi L (1983) Context effects: translation of UAG codon by suppressor tRNA is affected by the sequence following UAG in the message. J Mol Biol 164:73-87

Brierly I, Boursnell ME, Binns MM, Bilimoria B, Block VC, Brown TDK, Inglis SC (1987) An efficient ribosomal frameshifting signal in the polymerase-encoding region of the coronavirus IBV. EMBO J 6:3779-3785

Bunn HF, Forget BG (1986) Hemoglobin: molecular, genetics and clinical aspects. Sanders, Philadelphia USA

Capecchi MR, Vonder Haar RA, Capecchi NE, Sveda MM (1977) The isolation of a suppressible nonsense mutant in mammalian cells. Cell 12:371-381 
Capone JP, Sharp PA, RajBhandary UL (1985) Amber, ochre and opal suppressor tRNA genes derived from a human serine tRNA gene. EMBO J 4:213-221

Capone JP, Sedivy JM, Sharp PA, RajBhandary UL (1986) Introduction of UAG, UAA, and UGA nonsense mutations at a specific site in the Escherichia coli chloramphenicol acetyltransferase gene: use in measurement of amber, ochre, and opal suppression in mammalian cells. Mol Cell Biol 6:3059-3067

Celis JE, Piper PW (1981) Nonsense suppressors in eukaryotes. Trends Biochem Sci 6:177-179

Chakrabarti L, Guyader M, Alizon M, Daniel MD, Desrosiers RC, Tiollais P, Sonigo P (1987) Sequence of simian immunodeficiency virus from macaque and its relationship to other human and simian retroviruses. Nature 328:543-547

Chambers I, Harrison PR (1987) A new puzzle in selenoprotein biosynthesis: selenocysteine seems to be encoded by the 'stop' codon, UGA. Trends Biochem Sci 12:255-256

Chambers I, Frampton J, Goldfarb P, Affara N, McBain W, Harrison PR (1986) The structure of the mouse gluthione peroxidase gene: the selenocysteine in the active site is encoded by the 'termination' codon, TGA. EMBO J 5:1221-1227

Chen S-H, Habib G, Yang C-Y, Gu Z-W, Lee BR, Weng S-A, Silberman SS, Cai S-J, Deslypere JP, Rosseneu M, Gotto AM Jr, Li W-H, Chan L (1987) Apolipoprotein B-48 is the product of a messenger RNA with an organ-specific in-frame stop codon. Science 238:363-366

Craigan WJ, Caskey CT (1987) Translational frameshifting: where will it stop? Cell 50:1-2

Cremer KJ, Bodemer M, Summers WP, Summers WC, Gesteland RF (1979) In vitro suppression of UAG and UGA mutants in the thymidine kinase gene of Herpes simplex virus. Proc Natl Acad Sci USA 76:430-434

Crick FHA (1966) Codon-anticodon pairing: the wobble hypothesis. J Mol Biol 19:548-555

Davidson NO, Powell LM, Wallis SC, Scott J (1988) Thyroid hormone modulates the introduction of a stop codon in rat liver apolipoprotein B messenger RNA. J Biol Chem 263:13482-13485

Dayhuff TJ, Atkins JF, Gesteland RF (1986) Characterization of ribosomal frameshift events by protein sequence analysis. J Biol Chem 261:7491-7500

Diamond A, Dudock B, Hatfield D (1981) Structure and properties of a bovine liver UGA suppressor serine tRNA with a tryptophan anticodon. Cell 25:497-506

Efstratiadis A, Kafatos F, Maniatis T (1977) The primary structure of rabbit $\beta$-globin mRNA as determined from cloned DNA. Cell 10:571-585

Eggertsson G, Söll D, (1988) Transfer ribonucleic acid-mediated suppression of termination codons. Microbiol Rev 52:354-374

Engelberg-Kulka H, Schoulaker-Schwarz R (1988a) Stop is not the end: physiological implications of translational readthrough. J Theor Biol 131:477-485

Engelberg-Kulka H, Schoulaker-Schwarz R (1988b) A flexible genetic code, or why does selenocysteine have no unique codon? Trends Biochem Sci 13:419-421

Feng Y-X, Dong L, Zhang Y (1986) Homogeneous sequence in the anticodon of natural UAG suppressor tRNA ${ }^{\mathrm{Tyr}}$. Acta Biochim Biophys Sinica 18:90-95

Feng Y-X, Hatfield D, Rein A, Levin JG (1989a) Translational readthrough of the murine leukemia virus gag gene amber codon does not require virus-induced alteration of tRNA. J Virol 63:2405-2410

Feng Y-X, Levin J, Hatfield D, Schaefer T, Gorelick R, Rein A (1989b) Suppression of UAA and UGA termination codons in mutant murine leukemia virus. J Virol 63:2870-2873

Franchini G, Gurgo C, Guo H-G, Gallo RC, Collalti E, Fragnoli KA, Hall LF, Wong-Stahl F, Reitz MS (1987) Sequence of simian immunodeficiency virus and its relationship to the human immunodeficiency viruses. Nature 328:539-543

Geller AI, Rich A (1980) UGA termination suppression tRNA ${ }^{\text {Trp }}$ active in rabbit reticulocytes. Nature 283:41-46

Gesteland R, Wills N (1979) Use of yeast suppressors for identification of adenovirus nonsense mutants. In: Celis JE, Smith JD (eds) Nonsense mutations and tRNA suppressors. Academic Press, London, pp 277-284

Gesteland RF, Wills N, Lewis JB, Grodzicker T (1977) Identification of amber and ochre mutants of the human virus Ad2 + ND1. Proc Natl Acad Sci USA 74:4567-4571

Guyader M, Emerman M, Sonigo P, Clavel F, Montagnier L, Alizon M (1987) Genome 
organization and transactivation of the human immunodeficiency virus type 2 . Nature 326:662-669

Hardman DA, Protter AA, Schilling JW, Kane JP (1987) Carboxyl terminal analysis of human B-48 protein confirms the novel mechanism proposed for chain termination. Biochem Biophys Res Commun 149:1214-1219

Harley CB, Pollard JW, Stanners CP, Goldstein S (1981) Model for messenger RNA translation during amino acid starvation applied to the calculation of protein synthetic error rates. J Biol Chem 156:10786-10794

Hatfield D(1972) Recognition of nonsense codons in mammalian cells. Proc Natl Acad Sci USA 69:3014-3018

Hatfield D (1985) Suppression of termination codons in higher eukaryotes. Trends Biochem Sci 10:201-204

Hatfield D, Nirenberg M (1971) Binding of radioactive oligonucleotides to ribosomes Biochemistry 10:4318-4323

Hatfield D, Portugal FH (1970) Seryl-tRNA in mammalian tissues: chromatographic differences in brain and liver and a specific response to the codon UGA. Proc Natl Acad Sci USA 67:1200-1206

Hatfield D, Rice M (1986) Aminoacyl-tRNA (anticodon): codon adaptation in human and rabbit reticulocytes. Biochem Int 13:835-842

Hatfield D, Matthews CR, Rice M (1979) Aminoacyl-transfer RNA populations in mammalian cells: chromatographic profiles and patterns of codon recognition. Biochim Biophys Acta 564:414-423

Hatfield D, Diamond A, Dudock B (1982a) Opal suppressor serine tRNAs from bovine liver form phosphoseryl-tRNA. Proc Natl Acad USA 79:6215-6219

Hatfield D, Varricchio F, Rice M, Forget BG (1982b) The aminoacyl-tRNA population of human reticulocytes. J Biol Chem 257:3183-3188

Hatfield D, Dudock BS, Eden FC (1983) Characterization and nucleotide sequence of a chicken gene encoding an opal suppressor tRNA and its flanking DNA segments. Proc Natl Acad Sci USA 80: 4940-4944

Hatfield D, Thorgeirsson SS, Copeland TD, Oroszlan S, Bustin M (1988) Immunopurification of the suppressor tRNA dependent rabbit beta-globin readthrough protein. Biochemistry 27:1179-1183

Hatfield D, Feng Y-X, Lee BJ, Rein A, Levin JG, Oroszlan S (1989) Chromatographic analysis of aminoacyl-tRNAs which are required for translation of codons at and around the ribosomal frameshift sites in HIV, HTLV-1, and BLV. Virology 173:736-742

Hatfield D, Smith DWE, Lee BJ, Worland PJ, Oroszlan S (1989) Structure and function of suppressor tRNAs in higher eukaryotes. CRC critical reviews in biochemistry. CRC Press (in press)

Herr W (1984) Nucleotide sequence of AKV murine leukemia virus. J Virol 49:471-478

Higuchi K, Hospattankar AV, Law SW, Meglin N, Cortright J, Brewer HB Jr (1988) Human apolipoprotein B (apoB) mRNA: identification of two distinct apoB mRNAs, an mRNA with the apo-B-100 sequence and an apoB mRNA containing a premature in-frame translational stop codon, in both liver and intestine. Proc Natl Acad Sci USA 85:1772-1776

Hill CW (1975) Informational suppression of missense mutations. Cell 6:419-427

Hiramatsu K, Nishida J, Naito A, Yoshikura H (1987) Molecular cloning of the closed circular provirus of human T cell leukemia virus type I: a new open reading frame in the gag-pol region. J Gen Virol 68:213-218

Hizi A, Henderson LE, Copeland TD, Sowder RC, Hixson CV, Oroszlan S (1987) Characterization of mouse tumor virus gag-pol gene products and the ribosomal frameshift site by protein sequencing. Proc Natl Acad Sci USA 84:7041-7045

Ho Y-S, Kan YW (1987) In vivo aminoacylation of human and Xenopus suppressor tRNAs constructed by site-specific mutagenesis. Proc Natl Acad Sci USA 84:2185-2188

Ho Y-S, Norton GP, Palese P, Dozy AM, Kan YW (1986) Expression and function of suppressor tRNA genes in mammalian cells. Cold Spring Harbor Symposium on Quantitative Biology vol 51, Cold Spring Harbor, New York, pp 1033-1040

Hudziak RM, Laski FA, RajBhandary UL, Sharp PA, Capecchi MR (1982) Establishment of 
mammalian cell lines containing multiple nonsense mutations and functional suppressor tRNA genes. Cell 31:137-146

Inoue J-I, Watanabe T, Sato M, Oda A, Toyoshima K, Yoshida M, Seiki M (1986) Nucleotide sequence of the protease-coding region in an infectious DNA of simian retrovirus (STLV) of the HTLV-1 family. Virology 150:187-195

Ishikawa M, Meshi T, Motoyoshi F, Takamatsu N, Okada Y (1986) In vitro mutagenesis of the putative replicase genes of tobacco mosaic virus. Nucleic Acids Res 14:8291-8305

Jacks T, Varmus HE (1985) Expression of the Rous sarcoma virus pol gene by ribosomal frameshifting. Science 230:1237-1242

Jacks T, Townsley K, Varmus HE, Majors J (1987) Two efficient ribosomal frameshifting events are required for synthesis of mouse mammary tumor virus gag-related polyproteins. Proc Natl Acad Sci USA 84:4298-4302

Jacks T, Madhani HD, Masiraz FR, Varmus HE (1988a) Signals for ribosomal frameshifting in the Rous sarcoma virus gag-pol region. Cell 55:447-458

Jacks T, Power MD, Masiarz FR, Luciw PA, Barr PJ, Varmus H (1988b) Characterization of ribosomal frameshifting in HIV-1 gag-pol expression. Nature 331:280-283

Jackson RJ, Hunt T (1983) Preparation and use of nuclease-treated rabbit reticulocyte lysates for the translation of eukaryotic messenger RNA. Methods Enzymol 96:50-74

Jank P, Shindo-Okada N, Nishimura S, Gross HJ (1977) Rabbit liver tRNA ${ }_{1}^{\text {Val. primary }}$ structure and unusual codon recognition. Nucletic Acids Res 4:1999-2008

Johnson PF, Abelson J (1983) The yeast tRNA ${ }^{\mathrm{Tyr}}$ gene intron is essential for correct modification of its tRNA product. Nature 302:681-687

Kato N, Hoshino H, Harada F (1983) Minor serine tRNA containing anticodon NCA(C4 RNA) from human and mouse cells. Biochem Int 7:635-645

Kawakami T, Sherman L, Dahlberg J, Gazit A, Yaniv A, Tronick SR, Aaronson SA (1987) Nucleotide sequence analysis of equine infectious anemia virus proviral DNA. Virology 158:300-312

Kohli J, Grosjean H (1981) Usage of the three termination codons: compilation and analysis of known eukaryotic and prokaryotic translation termination sequences. Mol Gen Genet 182:430-439

Kohli J, Kwong T, Altruda F, Söll D (1979) Characterization of a UGA-suppressing serine tRNA from Schizosaccharomyces pombe with the help of a new in vitro assay system for eukaryotic suppressor tRNAs. J Biol Chem 254:1546-1551

Körner AM, Freinstein SI, Altman S (1978) Transfer RNA-mediated suppression. In: Altman S (ed) Transfer RNA. MIT Press, Cambridge, pp 105-135

Kubli E, Schmidt T, Martin PF, Sofer W (1982) In vitro suppression of a nonsense mutant of Drosophila melanogaster. Nucleic Acids Res 10:7145-7152

Kuchino Y, Borek E, Grunberger D, Mushinski J, Nishimura S (1982) Changes of posttranscriptional modification of Wye base in tumor-specific tRNA ${ }^{\text {Phe }}$. Nucleic Acids Res 10:6421-6432

Kuchino Y, Beier H, Akita N, Nishimura S (1987) Natural UAG suppressor glutamine tRNA is elevated in mouse cells infected with Moloney murine leukemia virus. Proc Natl Acad Sci USA 84:2668-2672

Kuchino Y, Nishimura S, Schröder HC, Rottmann M, Müller WEG (1988) Selective inhibition of formation of suppressor glutamine tRNA in Moloney murine leukemia virus-infected NIH-3T3 cells by Avarol. Virology 165:518-526

Laski FA, Belagaje R, RajBhandary UL, Sharp PA (1982) An amber suppressor tRNA gene derived by site-specific mutagenesis: cloning and function in mammalian cells. Proc Natl Acad Sci USA 79:5813-5817

Laski FA, Belagaje R, Hudziak RM, Capecchi MR, Norton GP, Palese P, RajBhandary UL, Sharp PA (1984) Synthesis of an ochre suppressor tRNA gene and expression in mammalian cells. EMBO J 3:2445-2452

Lee BJ, Kang SG, Hatfield D (1989a) Transcription of Xenopus selenocysteyl-tRNA ${ }^{\text {Ser }}$ (formerly designated opal suppressor phosphoserine tRNA) is directed by mutiple 5' extragenic regulatory elements. J Biol Chem 264:9696-9702

Lee BJ, de la Pen̈a P, Tobian JA, Zasloff M, Hatfield D (1987) Unique pathway of expression of an opal suppressor phosphoserine tRNA. Proc Natl Acad Sci USA 84:6384-6388 
Lee BJ, Worland PJ, Davis J, Stadium TC, Hatfield D (1989b) Identification of a selenocysteyltRNA $^{\text {Ser }}$ in mammalian cells which recognizes the nonsense codon, UGA. J Biol Chem 264:9724-9727

Lehrman MA, Goldstein JL, Brown MS, Russell DW, Schneider WJ (1985) Internalizationdefective LDL receptors produced by genes with nonsense and frameshift mutations that truncate the cytoplasmic domain. Cell 41:735-743

Leinfelder W, Zehelein E, Mandrand-Berthelot M-A, Böck A (1988) Gene for a novel tRNA species that accepts L-serine and cotranslationally inserts selenocysteine. Nature 331:723725

Leinfelder W, Stadtman TC, Böck A (1989) Occurrence in vivo of selenocysteyl-tRNA ${ }^{\text {Ser }}$ in Escherichia coli: effect of sel mutants. J Biol Chem 264:9720-9723

Li G, Rice CM (1989) Mutagenesis of the in-frame opal termination codon preceeding nsP4 of Sindbis virus: studies of translational readthrough and its effect on virus replication. J Virol 63:1326-1337

Lin JP, Aker M, Sitney KC, Mortimer RL (1986) First position wobble in codon-anticodon pairing: amber suppression by a yeast glutamine tRNA. Gene 49:383-388

Mäenpää PH (1972) Seryl transfer RNA alterations during estrogen-induced phosvitin synthesis: quantitative assay of the hormone-responding species by ribosomal binding. Biochem Biophys Res Commun 47:971-974

Mäenpää PH, Bernfield MR (1970) A specific hepatic transfer RNA for phosphoserine. Proc Natl Acad Sci USA 67:688-695

Marlor RL, Parkhurst SM, Corces VG (1986) The Drosophila melanogaster gypsy transposable elements encodes putative gene products homologous to retroviral proteins. Mol Cell Biol 6:1129-1134

Marotta C, Wilson J, Forget BG, Weissman S (1977) Human globin messenger RNA: nucleotide sequences derived from complementary DNA. J Biol Chem 252:5040-5053

McAdam RA, Goundis D, Reid KBM (1988) A homozygous point mutation results in a stop codon in the ClqB-chain of a Clq-deficient individual. Immunogenetics 27:259-264

McBride OW, Rajagopalan M, Hatfield D (1987) Opal suppressor phosphoserine tRNA gene and pseudogene are located on human chromosomes 19 and 22, respectively. J Biol Chem 262:11163-11166

McBride OW, Mitchell A, Lee BJ, Mullenbach G, Hatfield D (1988) Gene for seleniumdependent glutathione peroxidase maps to human chromosomes 3, 21, and X. BioFactors $1: 285-292$

Meier F, Suter B, Grosjean H, Keith G, Kubli E (1985) Queuosine modification of the wobble base in tRNA ${ }^{\text {His }}$ influences in vivo decoding properties. EMBO J 4:823-827

Mietz JA, Grossman Z, Lueders KK, Kuff EL (1987) Nucleotide sequence of a complete mouse intracisternal A-particle genome: relationship to known aspects of particle assembly and function. J Virol 61:3020-3029

Miller JH, Albertini AM (1983) Effects of surrounding sequence on the suppression of nonsense codons. J Mol Biol 164:59-71

Mizutani T, Hashimoto A (1984) Purification and properties of suppressor seryl-tRNA: ATP phosphotransferase from bovine liver. FEBS Lett 169:319-322

Mizutani T, Hitaka T (1988) Stronger affinity of reticulocyte release factor than natural suppressor $\mathrm{tRNA}^{\mathrm{Ser}}$ for the opal termination codon. FEBS Lett 226:227-231

Mizutani T, Tachibana Y (1986) Possible incorporation of phosphoserine into globin readthrough protein via bovine opal suppressor phosphoseryl-tRNA. FEBS Lett 207:162-166

Mizutani T, Narihara T, Hashimoto A (1984) Purification and properties of bovine liver seryltRNA synthetase. Eur J Biochem 143:9-13

Mizutani T, Kanbe K, Kimura Y, Tachibana Y, Hitaka T (1988) Non-partition of opal suppressor phosphoseryl-transfer ribonucleic acid (tRNA) in phosphoserine aminotransferase catalysis. Chem Pharm Bull 36:824-827

Moore R, Dixon M, Smith R, Peters G, Dickson C (1987) Complete nucleotide sequence of a milk-transmitted mouse mammary tumor virus: two frameshift suppression events are required for translation of $g a g$ and pol. J Virol 61:480-490 
Mullenback GT, Tabrizi A, Irvine BD, Bell GI, Hallewell RA (1987) Sequence of a cDNA coding for human glutathione peroxidase confirms TGA encodes active site selenocysteine. Nucleic Acids Res 15:5484

Mullenback GT, Tabrizi A, Irvine BD, Bell GI, Tainer JA, Hallewell RA (1988) Selenocysteine's mechanism of incorporation and evolution revealed in cDNAs of three glutathione peroxidases. Protein Engineer 2:239-246

Müller WEG, Schröder HC, Reuter P, Sarin PS, Hess G, Meyer zum Büschenfelde K-H, Kuchino Y, Nishimura S (1988) Inhibition of expression of natural UAG suppressor glutamine tRNA in HIV-infected human $\mathrm{H} 9$ cells in vitro by Avarol. AIDS Res Human Retrovir 4:279-286

Murgola EJ (1985) tRNA, suppression, and the code. Annu Rev Genet 19:57-80

Murgola EJ (1989) Mutant glycine tRNAs and other wonders of translation suppression. In: Cherayil JD (ed) Transfer RNAs and other soluble RNAs. CRC Press, Boca Raton, (in press)

Murphy EC Jr, Wills N, Arlinghaus RB (1980) Suppression of murine retrovirus polypeptide termination: effect of amber suppressor tRNA on the cell-free translation of Rauscher murine leukemia virus, Moleney murine leukemia virus, and Moloney murine sarcoma virus 124 RNA. J Virol 34:464-473

Nam SH, Kidokoro M, Shida H, Hatanka M (1988) Processing of gag precursor polyprotein of human T-cell leukemia virus type I by virus-encoded protease. J Virol 62:3718-3728

Nirenberg M, Leder P (1964) RNA codewords and protein synthesis: the effect of trinculeotides upon the binding of sRNA to ribosomes. Science 145:1399-1407

O'Neill VA, Eden FC, Pratt K, Hatfield D (1985) A human opal suppressor tRNA gene and pseudogene. J Biol Chem 260:2501-2508

Panganiban AT (1988) Retroviral gag gene amber codon suppression is caused by an intrinsic cis-acting component of the viral mRNA. J Virol 62:3574-3580

Parker J, Pollard JW, Friesen JD, Stanners CP (1978) Stuttering: high-level mistranslation in animal and bacterial cells. Proc Natl Acad Sci USA 75:1091-1095

Pelham HRB (1978) Leaky UAG termination codon in tobacco mosaic virus RNA. Nature 272:469-471

Philipson L, Andersson P, Olshevsky U, Weinberg R, Baltimore D (1978) Translation of MuLV and MSV RNAs in nuclease-treated reticulocyte extracts: enhancement of the gag-pol polypeptide with yeast suppressor tRNA. Cell 13:189-199

Pollard J, Harley CB, Chamberlin JW, Goldstein S, Stanners CP (1982) Is transformation associated with an increased error frequency in mammalian cells? J Biol Chem 257:59775979

Powell LM, Wallis SC, Pease RJ, Edwards YH, Knott TJ, Scott J (1987) A novel form of tissuespecific RNA processing produces apolipoprotein-B48 in intestine. Cell 50:831-840

Power MD, Marx PA, Bryant ML, Gardner MB, Barr PJ, Luciw PA (1986) Nucleotide sequence of SRV-1, a type D simian acquired immune deficiency syndrome retrovirus. Science 231:1567-1572

Pratt K, Eden FC, You KH, O'Neill VA, Hatfield D (1985) Conserved sequences in both coding and 5 ' flanking regions of mammalian opal suppressor tRNA genes. Nucleic Acids Res $13: 4765-4775$

Pure GA, Robinson GW, Naumovski L, Friedberg EC (1985) Partial suppression of an ochre mutation in Saccharomyces cerevisiae by multicopy plasmids containing a normal yeast tRNA ${ }^{\text {Gln }}$ gene. J Mol Biol 183:31-42

Raba M, Limberg K, Burghagen M, Katze JR, Simsek M, Heckman JE, RajBhandary UL, Gross HJ (1979) Nucleotide sequence of three isoaccepting lysine tRNAs from rabbit liver and SV40-transformed mouse fibroblast. Eur J Biochem 97:305-318

Ratner L, Haseltine W, Patarca R, Livak KJ, Starcich B, Josephs SF, Doran ER, Rafalski JA, Whitehorn EA, Baumeister K, Ivanoff J, Petteway SR, Pearson ML, Lautenberger JA, Papas TS, Ghrayeb J, Chang NT, Gallo RC, Wong-Staal F (1985) Complete nucleotide sequence of the AIDS virus, HTLV-III. Nature 313:277-284

Reddy AP, Hsu BL, Reddy PS, Li N-Q, Thyagaraju K, Reddy CC, Tam MF, Tu C-PD (1988) Expression of glutathione peroxidase I gene in selenium-deficient rats. Nucleic Acids Res 16:5557-5568 
Rice NR, Stephens R, Burny A, Gilden R (1985) The gag and pol genes of bovine leukemia virus: nucleotide sequence and analysis. Virology 142:357-377

Roberts BE, Paterson BM (1973) Efficient translation of tobacco mosaic virus RNA and rabbit globin 9S RNA in a cell-free system from commercial wheat germ. Proc Natl Acad Sci USA 70:2330-2334

Romeo G. Hassan HJ, Staempfli S, Roncuzzi L, Cianetti L, Leonardi A, Vicente V, Mannucci PM, Bertina R, Peschle C, Cortese R (1987) Hereditary thrombophilia: identification of nonsense and missense mutations in the protein $C$ gene. Proc Natl Acad Sci USA 84:28292832

Sagata N, Yasunaga T, Tsuzuku-Kawamura J, Ohishi K, Ogawa Y, Ikawa Y (1985) Complete nucleotide sequence of the genome of bovine leukemia virus: its evolutionary relationship to other retroviruses. Proc Natl Acad Sci USA 82:677-681

Saigo K, Kugiyama W, Matsuo Y, Inouye S, Yoshioka K, Yuki S (1984) Identification of the coding sequence for a reverse transcriptase-like enzyme in a transposable genetic element in Drosophila melanogaster. Nature 312:659-663

Sanchez-Pescador R, Power MD, Barr PJ, Steimer KS, Stempien MM, Brown-Shimer SL, Gee WW, Renard A, Randolph A, Levy JA, Dina D, Luciw PA (1985) Nucleotide sequence and expression of AIDS-associated retrovirus (ARV-2). Science 227:484-492

Satoh K, Nukiwa T, Brantly M, Garver RI Jr, Hofker M, Courtney M, Crystal RG (1988) Emphysema associated with complete absence of $\alpha$ l-antitrypsin of a stop codon in an $\alpha \mathrm{l}-$ antitrypsin-coding exon. Am J Human Genet 42:77-83

Schwartz DE, Tizard R, Gilbert W (1983) Nucleotide sequence of Rous sarcoma virus. Cell 32:853-869

Sedivy JM, Capone JP, RajBhandary UL, Sharp PA (1987) An inducible mammalian amber suppressor: propagation of a poliovirus mutant. Cell 50:379-389

Seiki M, Hattori S, Hirayama Y, Yoshida M (1983) Human adult T-cell leukemia virus: complete nucleotide sequence of the provirus genome integrated in leukemia cell DNA. Proc Natl Acad Sci USA 80:3618-3622

Sharp SJ, Stewart TS (1977) The characterization of phosphoseryl tRNA from lactating bovine mammary gland. Nucleic Acids Res 4:2123-2136

Sherman F (1982) Suppression in yeast Saccharomyces cerevisiae. In: Strathern JN, Jones EW, Broach JR (eds) Molecular biology of the yeast Saccharomyces; metabolism and gene expression. Cold Spring Harbor Laboratories, New York, pp 463-486

Shimotohno K, Takahashi Y, Shimizu N, Gojobori T, Golde DW, Chen IS, Miwa M, Sugimura $T$ (1985) Complete nucleotide sequence of an infectious clone of human T-cell leukemia virus type II: an open reading frame for the protease gene. Proc Natl Acad Sci USA 82:3101-3105

Shindo-Okada N, Akimoto H, Nomura H, Nishmura S (1985) Recognition of UAG termination codon by mammalian tyrosine tRNA containing 6-thioqueuine in the first position of the anticodon. Proc Jpn Acad 61:94-98

Shinnick TM, Lerner RA, Sutclife JG (1981) Nucleotide sequence of Moloney murine leukemia virus. Nature 293:543-548

Smith DWE, Hatfield D (1986) Effects of post-translational base modifications on the sitespecific function of transfer RNA in eukaryote translation. J Mol Biol 189:663-671

Smith DWE, McNamara AL (1982) The effect of the Q base modification on the usage of tRNA $^{\text {His }}$ in globin synthesis. Biochem Biophys Res Commun 104:1459-1463

Smith DWE, McNamara A, Rice M, Hatfield D (1981) The effects of a post-transcriptional modification on the function of tRNA ${ }^{\mathrm{Lys}}$ isoaccepting species in translation. J Biol Chem 256:10033-10036

Smith DWE, McNamara AL, Mushinski JF, Hatfield DL (1985) Tumor-specific, hypomodified phenylalanyl-tRNA is utilized in translation in preference to the fully modified isoacceptor of normal cells. J Biol Chem 260:147-151

Smith JD (1979) Suppressor tRNAs in prokaryotes. In: Celis JE, Smith JD (eds) Nonsense mutations and tRNA suppressors. Academic Press, London pp 109-125

Sonigo P, Alizon M, Staskus K, Klatzmann D, Cole S, Danos O, Retzel E, Tiollais O, Haase A, Wain-Hobson S (1985) Nucleotide sequence of the visna lentivirus: relationship to the AIDS virus. Cell 42:369-382 
Sonigo P, Barker C, Hunter E, Wain-Hobson S (1986) Nucleotide sequence of Mason-Pfizer monkey virus: an immunosuppressive D-type retrovirus. Cell 45:375-385

Sprinzl M, Hartmann T, Meissner F, Moll J, Vorderwülbecke T (1987) Compilation of tRNA sequences and tRNA genes. Nucleic Acids Res (Sequences supplement) 15:r53-r188

Steege DA, Söll DG (1979) Suppression. In: Goldberger RF (ed) Biological Regulation and Development (vol 1). Plenum, New York, pp 433-485

Stephens RM, Casey JW, Rice NR (1986) Equine infectious anemia virus gag and pol genes: relatedness to visna and AIDS virus. Science 231:589-594

Stewart T, Sharp S (1984) Characterizing the function of $\mathrm{O}^{\beta}$-phosphoseryl-tRNA. Methods Enzymol 106:157-161

Strauss EG, Rice CM, Strauss JH (1983) Sequence coding for the alphavirus nonstructural proteins is interrupted by an opal termination codon. Proc Natl Acad Sci USA 80:5271-5275

Strauss EG, Rice CM, Strauss JH (1984) Complete nucleotide sequence of the genomic RNA of Sindbis virus. Virology 133:92-110

Sukenaga Y, Ishida K, Takeda T, Takagi K (1987) cDNA sequence coding for human glutathione peroxidase. Nucleic Acids Res 15:7178

Summers WP, Summers WC, Laski FA, RajBhandary UL, Sharp PA (1983) Functional suppression in mammalian cells of nonsense mutations in the Herpes simplex virus thymidine kinase gene by suppressor tRNA genes. J Virol 47:376-379

Sundee RA, Evenson JK (1987) Serine incorporation into the selenocysteine moiety of glutathione peroxidase. J Biol Chem 262:933-937

Suter B, Altwegg M, Choffat Y, Kubli E (1986) The nucleotide sequence of two homogeneic Drosophila melanogaster tRNA ${ }^{\mathrm{Tyr}}$ isoacceptors: application of a rapid tRNA anticodon sequencing method using S-1 nuclease. Arch Biochem Biophys 247:233-237

Temple GF, Dozy AM, Roy KL, Kan YW (1982) Construction of a functional human suppressor tRNA gene: an approach to gene therapy for beta-thalassaemia. Nature 296:537-540

Thayer RM, Power MD, Bryant ML, Gardner MB, Barr PJ, Luciw PA (1987) Sequence relationships of type $D$ retroviruses which cause simian acquired immunodeficiency syndrome. Virology 157:317-329

Topal MD, Fresco JR (1976) Complementary base pairing and the origin of substitution mutations. Nature 263:285-289

Tukalo MA, Vlasov V, Vasil'chenko I, Matsuka G, Knorre D (1980) Dokl Akad Nauk SSSR 253:253-256

Valle RPC, Morch M-D (1988) Stop making sense or regulation at the level of termination in eukaryotic protein synthesis. FEBS Lett 235:1-15

Valle RPC, Morch M-D, Haenni A-L (1987) Novel amber suppressor tRNAs of mammalian origin. EMBO J 6:3049-3055

Vasilieva IG, Tukalo MA, Krikliviy IA, Matduka GCH (1984) Mol Biol Akad Nauk SSSR $18: 1321-1325$

Wain-Hobson S, Sonigo P, Danos O, Cole S, Alizon M (1985) Nucleotide sequence of the AIDS virus, LAV. Cell 40:9-17

Ward DC, Reich E (1968) Conformational properties of polyformycin: a polyribonucleotide with individual residues in the syn conformation. Proc Natl Acad Sci USA 61:1494-1501

Weiss WA, Friedberg EC (1986) Normal yeast tRNA ${ }^{\mathrm{Gln}} / \mathrm{CAG}$ can suppress amber codons and is encoded by an essential gene. J Mol Biol 192:725-735

Weiss RB, Dunn JF, Atkins JF, Gesteland RF (1987a) Slippery runs, shifty stops, backward steps, and forward hops: $-2,-1,+1,+2,+5$, and +6 ribosomal frameshifting. Cold Spring Harbor Symposia on Quantitative Biology vol II, Gold Spring Harbor, New York, pp 687-696

Weiss WA, Edelman I, Culbertson MR, Friedberg EC (1987b) Physiological levels of normal tRNA ${ }^{\text {Gln }} /$ CAG can effect partial suppression of amber mutations in the yeast Saccharomyces cerevisiae. Proc Natl Acad Sci USA 84:8031-8034 
Weiss R, Lindsley D, Falahee B, Gallant J (1988) On the mechanism of ribosomal frameshifting at hungry codons. J Mol Biol 203:403-410

Wilson W, Braddock M, Adams S, Rathjen P, Kingsman S, Kingsman A(1988) HIV expression strategies: ribosomal frameshifting is directed by a short sequence in both mammalian and yeast systems. Cell 55:1159-1169

Yoshinaka Y, Katosh I, Copeland TD, Oroszlan S (1985a) Murine leukemia virus protease is encoded by the gag-pol gene and is synthesized through suppression of an amber termination codon. Proc Natl Acad Sci USA 82:1618-1622

Yoshinaka Y, Katoh I, Copeland TD, Oroszlan S (1985b) Translational readthrough of an amber termination codon during synthesis of feline leukemia virus protease. J Virol $55: 870-873$

Young JF, Capecchi M, Laski FA, RajBhandary UL, Sharp PA, Palese P (1983) Measurement of suppressor transfer RNA activity. Science 221:873-875

Ziegler V, Richards K, Guilley H, Jonard T, Putz C (1985) Cell-free translation of beet necrotic yellow vein virus: readthrough of the coat protein cistron. J Gen Virol 66:2079-2087

Zinoni F, Birkmann A, Leinfelder E, Böck A (1987) Cotranslational insertion of selenocysteine into formate dehydrogenase from Escherichia coli directed by a UGA codon. Proc Natl Acad Sci USA 84:3156-3160 